\title{
Plutonic xenoliths from Martinique, Lesser Antilles: evidence for open system processes and reactive melt flow in island arc crust
}

\author{
George F. Cooper ${ }^{1} \cdot$ Jon P. Davidson $^{1} \cdot$ Jon D. Blundy ${ }^{2}$
}

Received: 24 April 2016 / Accepted: 9 September 2016 / Published online: 27 September 2016

(C) The Author(s) 2016. This article is published with open access at Springerlink.com

\begin{abstract}
The Lesser Antilles Volcanic Arc is remarkable for the abundance and variety of erupted plutonic xenoliths. These samples provide a window into the deeper crust and record a more protracted crystallisation history than is observed from lavas alone. We present a detailed petrological and in situ geochemical study of xenoliths from Martinique in order to establish their petrogenesis, pre-eruptive storage conditions and their contribution to construction of the sub-volcanic arc crust. The lavas from Martinique are controlled by crystal-liquid differentiation. Amphibole is rarely present in the erupted lavas, but it is a very common component in plutonic xenoliths, allowing us to directly test the involvement of amphibole in the petrogenesis of arc magmas. The plutonic xenoliths provide both textural and geochemical evidence of open system processes and crystal 'cargos'. All xenoliths are plagioclase-bearing, with variable proportions of olivine, spinel, clinopyroxene, orthopyroxene and amphibole, commonly with interstitial melt. In Martinique, the sequence of crystallisation varies in sample type and differs from other islands of the Lesser Antilles arc. The compositional offset between plagioclase $\left(\sim \mathrm{An}_{90}\right)$ and olivine $\left(\sim \mathrm{Fo}_{75}\right)$, suggests crystallisation under high
\end{abstract}

Communicated by Othmar Müntener, Editor in Chief.

Electronic supplementary material The online version of this article (doi:10.1007/s00410-016-1299-8) contains supplementary material, which is available to authorized users.

George F. Cooper

george.cooper@durham.ac.uk

1 Science Labs, Department of Earth Sciences, Durham University, Durham DH1 3LE, UK

2 School of Earth Sciences, University of Bristol, Wills Memorial Building, Bristol BS8 1RJ, UK water contents and low pressures from an already fractionated liquid. Texturally, amphibole is either equant (crystallising early in the sequence) or interstitial (crystallising late). Interstitial amphibole is enriched in Ba and LREE compared with early crystallised amphibole and does not follow typical fractionation trends. Modelling of melt compositions indicates that a water-rich, plagioclase-undersaturated reactive melt or fluid percolated through a crystal mush, accompanied by the breakdown of clinopyroxene, and the crystallisation of amphibole. Geothermobarometry estimates and comparisons with experimental studies imply the majority of xenoliths formed in the mid-crust. Martinique cumulate xenoliths are inferred to represent crystal mushes within an open system, through which melt can both percolate and be generated.

Keywords Lesser Antilles · Martinique · Plutonic · Xenoliths $\cdot$ Amphibole $\cdot$ Reactive melt

\section{Introduction}

Arc magmas are commonly highly differentiated and rarely represent primary mantle-derived melts. The vast majority of studies on arc magmatism are restricted to samples of the extrusive products, which represent the end products of magmatic processes that may occur over considerable time and depth ranges within the arc crust. On the other hand, plutonic xenoliths, representing erupted plutonic samples, have a greater preservation potential than phenocrysts in lavas and are therefore more likely to provide a window into the true fractionation history of magmas (Arculus and Wills 1980; Macdonald et al. 2000). The Lesser Antilles Arc is exceptional globally in respect to the abundance and variety of erupted plutonic xenoliths, which are the focus 


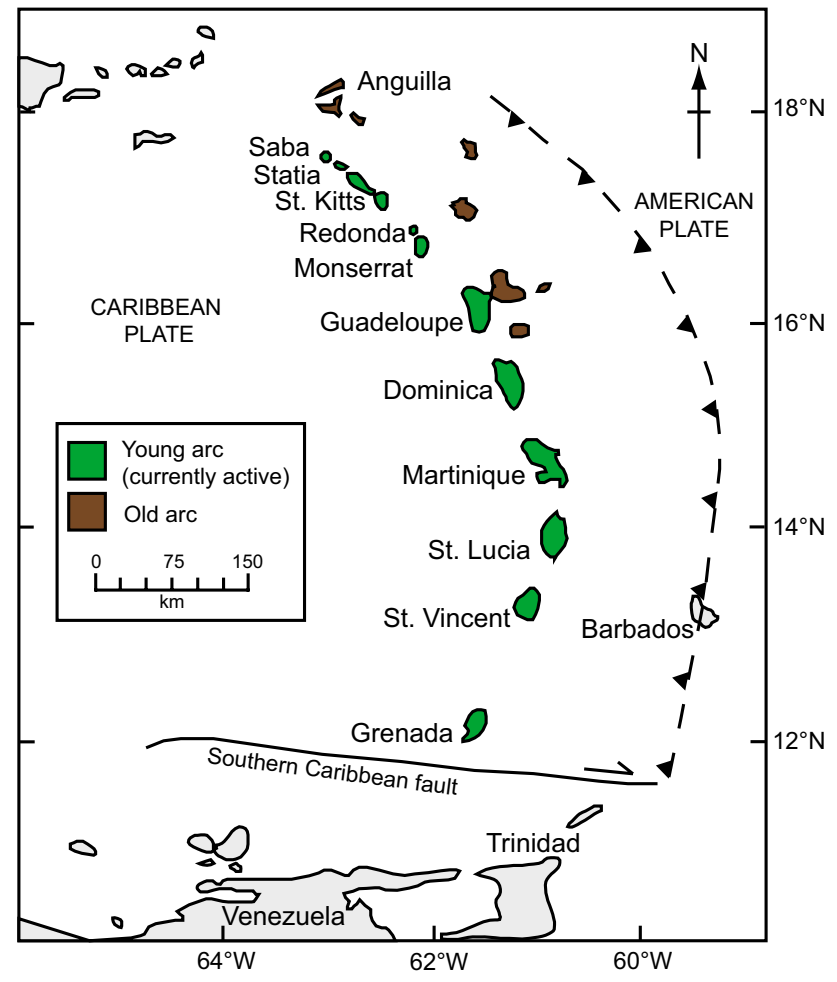

Fig. 1 Map of the Lesser Antilles Island arc. The dashed line depicts the approximate position of the subduction zone (after Wadge and Shepherd 1984). Islands making up the old arc (brown) and the currently active arc (green) are denoted

of several studies (Lewis 1973; Arculus and Wills 1980; Tollan et al. 2012; Stamper et al. 2014). Therefore, the Lesser Antilles is an ideal location to study the relationship between extrusive and intrusive components of an arc magmatic system. Our focus is the island of Martinique in the centre of the Lesser Antilles arc (Fig. 1). We present a detailed petrological, mineralogical and in situ geochemical study of a diverse collection of plutonic xenoliths from Martinique in order to establish the mode of formation and the conditions in which they were stored, with the aim of establishing a model of the components making up the crust and the sub-volcanic plumbing system beneath the island. We use an extensive dataset to address the following key questions: Where in the crust do the plutonic xenoliths originate from? Do the samples record crystallisation within a closed system, or do they represent a crystal mush undergoing open system processes? To what extent do the plutonic xenoliths represent cumulates versus frozen portions of magma? How does the mineral chemistry vary depending on the evolutionary history? What are the processes which led to the crystallisation of contrasting amphiboles?

There are a vast number of studies focussed on in situ mineral chemistry of volcanic rocks; however, the majority of geochemical and isotopic studies on plutonic rocks have concentrated on whole-rock data. For this study, we focus on the in situ trace element concentrations of mineral phases contained within a range of plutonic xenolith types. Trace element variations (in this case, by laser ablation ICP-MS) in crystal phases provide a means to track processes throughout the magmatic history of the plutonic xenoliths and the conditions in which they were formed. By analysing thin sections directly, the textural relationships of the analysed mineral phases can be assessed, therefore allowing us to compare the formation processes of different plutonic xenolith types and the nature of parental melts.

The formation and evolution of cumulates and/or crystal mushes has been studied for layered intrusions such as Skaergaard (McBirney and Noyes 1979; McKenzie 2011) and Rum (Bédard et al. 1988; Holness 2005; Holness et al. 2007; Leuthold et al. 2014). The generation of cumulates was traditionally thought to involve crystal settling onto the base of the magma chamber and then subsequent evolution of the interstitial liquid through crystal growth and compaction in a closed system (Wager et al. 1960). Solidification likely occurs at magma chamber margins, and therefore exchange of melt to and from the magma chamber may occur. Crystallisation under these conditions is termed in situ crystallisation (McBirney and Noyes, 1979). However, these models are unlikely to work in hydrous systems such as active island arcs (Meurer and Claeson 2002). Cumulate rocks from exposed arc crustal sections (Murray 1972; Greene et al. 2006; Bouilhol et al. 2015; Stuart et al. 2015) and plutonic xenoliths (Smith 2014; Stamper et al. 2014) can also record evidence for open system processes such as multiple magma replenishment episodes or percolating melts. Recently, the evolving liquids interacting with crystal mush and/or cumulate can be traced through the use of in situ trace element concentrations (Meurer and Claeson 2002) and large variations in incompatible trace elements may indicate an open system and an addition of melts into a crystal mush or cumulate pile. Here we investigate the extent of closed and open system processes recorded by plutonic xenoliths.

Amphibole is rarely present in the erupted volcanic products of the Lesser Antilles (with the exception of Montserrat), but it is a very common component in plutonic xenoliths from every island of the Lesser Antilles arc. The trace element signatures of arc lavas suggest that in a water-rich, mid- to lower sub-arc crust, the fractionation of amphibole imparts a control on the differentiation of arc magmas - the amphibole 'sponge' model of Davidson et al. (2007). This model is supported by the presence of ultracalcic nepheline-normative melts in the lesser Antilles and other island arcs worldwide, which may be generated by the melting of olivine-clinopyroxene-amphibole cumulates in the lower arc crust (Schiano et al. 2000; Médard et al. 2004). The 
plutonic xenoliths from Martinique therefore allow us to directly test what the involvement of amphibole and "cryptic' amphibole fractionation (Davidson et al. 2007) has on the petrogenesis of erupted arc magmas and the depths in the crust where these melts are stored and generated. Here, we study amphiboles with contrasting textural relationships and trace element signatures to explore the different magmatic processes involved in their formation.

\section{Geological setting}

The lesser Antilles Arc is located along the eastern margin of the Caribbean plate as the result of the relatively slow ( $\sim 2 \mathrm{~cm} /$ year) westward subduction of the Atlantic oceanic lithosphere. The arc is $750 \mathrm{~km}$ long, and to the north it bifurcates into an older arc to the east and the recent arc to the west (Fig. 1). The distinct westward jump occurred at $\sim 7 \mathrm{Ma}$ and has been attributed to the flattening of the subducting slab by the subduction of an aseismic ridge (Bouysse and Westercamp 1990). There is an extensive geochemical variation along the arc, which to a first order is systematic, (Brown et al. 1977; Smith et al. 1980; Turner et al. 1996; Macdonald et al. 2000), although the large geochemical and isotopic variations at each volcanic centre add to the complexity (Bezard et al. 2015). In general, islands in the north (Saba to Montserrat) produce low-K basalts, whereas those to the south (Grenadines and Grenada) produce medium-K picrites and ankaramites (Macdonald et al. 2000) and only the southern islands have mafic magmas with $>8 \mathrm{wt} \% \mathrm{MgO}$ and associated mantlederived xenoliths (Arculus 1976; Heath et al. 1998). The central islands are typically composed of medium-K basalt or basaltic andesite, although many islands have both lowand medium-K lavas (Macdonald et al. 2000).

Seismic refraction experiments (Boynton et al. 1979) and receiver function analysis (Schlaphorst et al. 2014) reveal a significant variation in the depth of both the inferred $\mathrm{MOHO}$ and Conrad discontinuity along the length of the Lesser Antilles volcanic arc. Similar along strike crustal variations have been linked to geochemical composition of the erupted volcanic products, such as in the IzuBonin intra-oceanic arc (Kodaira et al. 2007; Tamura et al. 2009). This implies that the crustal structure imparts a control on the petrogenesis of arc lavas. In this study, we are able to directly analyse parts of an active plumbing system, at a potentially diverse range of depths, in order to test the petrogenetic controls of Lesser Antilles arc crust.

Martinique is located in the central arc at the point where the old and current arcs diverge and therefore it displays a complete geologic history of the arc, spanning at least the last $25 \mathrm{Myr}$ (Germa et al. 2011). Distinct volcanic phases make up the old, intermediate and recent volcanic activity in Martinique (Labanieh et al. 2012). The lavas contain, in order of abundance, phenocrysts of: plagioclase, orthopyroxene and clinopyroxene. Amphibole is typically absent and when present $(<5 \%)$ it is opacitized (Davidson and Wilson 2011). The lavas from Martinique cover most of the chemical and isotopic variability known in the Lesser Antilles arc (Davidson 1983, 1986; Davidson and Wilson 2011). The large range in isotopic compositions displayed in Martinique lavas is attributed to the incorporation of slab-derived sediment, as well as the addition of sediment melt and fluid via crustal contamination. (Davidson and Wilson 2011). The question then arises as to whether the plutonic counterparts to the lavas also display the same level of geochemical heterogeneity, or whether the processes responsible for the compositional variation occurred in shallow melt-dominant bodies, unrelated to cumulate crystallisation.

Numerous studies have focused on plutonic xenoliths from the Lesser Antilles volcanic arc. Arculus and Wills (1980) provided the first detailed petrological study reporting that the compositions of phases within cumulate xenoliths were distinct from the phenocrysts in associated eruptives. The majority of xenoliths are ad- and heteradcumulates with fewer ortho- and crescumulates. Plagioclase, amphibole, clinopyroxene, orthopyroxene, olivine, magnetite, biotite, ilmenite, quartz and apatite are present in various proportions, and interstitial glass is often present (Arculus and Wills 1980). Significant variation along the arc manifested in the rarity of orthopyroxene and abundance of amphibole in the southern islands, compared with the common presence of two pyroxenes in the northern islands (Arculus and Wills 1980). Plutonic xenoliths from each individual island have distinctive characteristics in terms of mineralogy and petrology (e.g. Arculus and Wills 1980; Kiddle et al. 2010; Stamper et al. 2014; Tollan et al. 2012) which influences the petrology and geochemistry of the juvenile erupted material on each of the islands.

\section{Analytical techniques}

Whole-rock major $\left(\mathrm{SiO}_{2}, \mathrm{TiO}_{2}, \mathrm{Al}_{2} \mathrm{O}_{3}, \mathrm{Fe}_{2} \mathrm{O}_{3}, \mathrm{MnO}, \mathrm{MgO}\right.$, $\mathrm{CaO}, \mathrm{Na}_{2} \mathrm{O}, \mathrm{K}_{2} \mathrm{O}, \mathrm{P}_{2} \mathrm{O}_{5}$ ) and selected trace elements $(\mathrm{V}, \mathrm{Cr}$, $\mathrm{Rb}, \mathrm{Nb}, \mathrm{Sr}, \mathrm{Y}, \mathrm{Zn}, \mathrm{Co}, \mathrm{Ni}, \mathrm{Ba}$ ) were analysed by $\mathrm{X}$-ray fluorescence spectrometry using a Siemens SRS 3000 sequential XRF spectrometer at the University of Auckland.

Whole-rock trace element analysis was carried out by solution ICP-MS on a ThermoScientific X-Series 2 ICPMS at Durham University. W-2, BHVO-1 and AGV-1 standards were used to monitor accuracy and precision (Online Resource 1).

Major element concentrations of minerals were analysed in situ on polished thin sections with Cameca SX100 and JEOL JXA8530F electron microprobes at the University of Bristol. The Cameca SX100 was run with a $20 \mathrm{kV}$ 
accelerating voltage, a $20 \mathrm{nA}$ beam current and a $1 \mu \mathrm{m}$ spot size. The JEOL JXA8530F was run with a $15 \mathrm{kV}$ accelerating voltage, a $10 \mathrm{nA}$ beam current and a $1 \mu \mathrm{m}$ spot size. The instruments were calibrated using synthetic oxide, mineral and metal standards. Typical detection limits are presented in Online Resource 1.

Trace element concentrations of minerals were determined by laser ablation ICP-MS using a New Wave UP193FX laser ablation system coupled to a ThermoScientifc X- Series 2 ICP-MS at Durham University. Analyses were made in situ on the same polished thin sections used for major element analyses. Mineral major element concentrations were determined for each analytical spot by EPMA prior to LA-ICP-MS analysis. This ensures major and trace element concentrations could be coupled and an accurate ${ }^{43} \mathrm{Ca}$ (or ${ }^{29} \mathrm{Si}$ ) value could be used to normalise LA-ICP-MS data. A spot size of $75 \mu \mathrm{m}$ was used at a laser repetition rate of $5 \mathrm{~Hz}$ and a pulse energy of $\sim 5 \mathrm{~mJ}$. Helium was used as the carrier gas. The NIST 612 and NIST 610 glasses were used for calibration and to monitor instrumental drift. BCR-2G and BHVO-2G were used as secondary standards and were analysed during each analytical session (uncertainties presented in Online Resource 1).

\section{Results}

\section{Plutonic xenolith samples}

All studied samples are coarse-grained intrusive rocks and are here termed, collectively, plutonic xenoliths. They have been named using the classification scheme of Streckeisen (1976) and are only termed cumulate if the bulk composition, textures and mineral chemistry is consistent with them being a subtractive assemblage. If its cumulate origin cannot be demonstrated through geochemistry, we refer to the rock as a 'non-cumulate gabbro', which in this case, represents a magma that has solidified without significant movement of crystals with respect to the host melt. The majority of plutonic xenoliths used in this study were sourced in the north of Martinique, where the most recent phases of volcanism are focussed (Westercamp et al. 1989; Germa et al. 2011). Most xenoliths were sampled ex situ, from riverbeds where they have become gravitationally concentrated. Therefore, samples cannot be directly linked to the deposits in which they were erupted originally. However, the samples used here are inferred to be from Mount Peleé (126-0 ka) and Mount Conil (550-127 ka) (Westercamp et al. 1989; Germa et al. 2011). The Mount Conil complex is made up of andesitic breccias, lava domes and lava flows, the majority of which are now buried beneath the younger explosive deposits of Mount Peleé (Germa et al. 2011), which dominates the north end of the island.
The relative crystallisation sequence of each plutonic xenolith can be determined through textural inspection and this varies between sample types (Fig. 2). Where present, olivine is always the first phase to crystallise, followed by plagioclase which is ubiquitous and the dominant mineral phase in almost all samples (Figs. 2, 3). In general, clinopyroxene is the next phase to crystallise (co-crystallising with orthopyroxene in gabbronorites). The appearance of spinel varies from the last crystallising phase in olivine gabbros, after plagioclase in gabbronorites and the first crystallising phase in a hornblende gabbro sample. In contrast to the lavas, amphibole is an abundant phase, in addition to clinopyroxene and olivine. Amphibole is either present as an early crystallising phase alongside plagioclase and clinopyroxene or has crystallised at a late stage and is interstitial to the cumulus assemblage. Late-stage, interstitial amphibole appears to be texturally associated with clinopyroxene, and we explore this relationship below, with in situ trace element chemistry. Orthopyroxene is present in a number of clinopyroxene bearing samples.

Many samples display variations in modal layering, textures and degree of interstitial melt present. Adcumulate, heteradcumlate and orthocumulate textures are present within Martinique plutonics and a component of interstitial vesiculated glass is a common feature, giving rise to a disaggregated appearance (Fig. 3). Where in contact with interstitial glass, plagioclase may display a lower An rim, representing post-cumulus reaction with the melt. Melt inclusions are very rare within samples from Martinique. The plutonics can be divided into the following rock types: troctolites, olivine gabbros, hornblende-olivine gabbros, hornblende gabbros, plagioclase hornblendites, hornblende gabbronorites and gabbronorites.

\section{Plutonic types}

Troctolites $(\mathrm{ol}+$ plag $)$ are dominated by large plagioclase grains $(\leq 1 \mathrm{~cm})$ with smaller $(\leq 3 \mathrm{~mm}$ [majority $\ll 1 \mathrm{~mm}$ ]) irregular shaped, generally unzoned olivine, which is found both included within plagioclase and along grain boundaries (Fig. 3a). Interstitial vesiculated brown glass is present, and olivine is normally zoned with respect to $\mathrm{Fe}-\mathrm{Mg}$ where in contact with the glass. Plagioclase is unzoned within troctolite samples.

Olivine gabbros $(\mathrm{ol}+\mathrm{plag}+\mathrm{cpx} \pm \mathrm{spl})$ have a striking texture dominated by large poikilitic plagioclase grains $(\leq 5 \mathrm{~mm})$ with very small unzoned olivine inclusions $(<0.5 \mathrm{~mm})$ (Fig. 3b). Smaller plagioclase grains $(<1 \mathrm{~mm})$ are found interstitially together with poikilitic clinopyroxene $(<10 \%,<2 \mathrm{~mm})$ and minor spinel, which contain both plagioclase and olivine. Plagioclase is unzoned within olivine gabbro samples. 


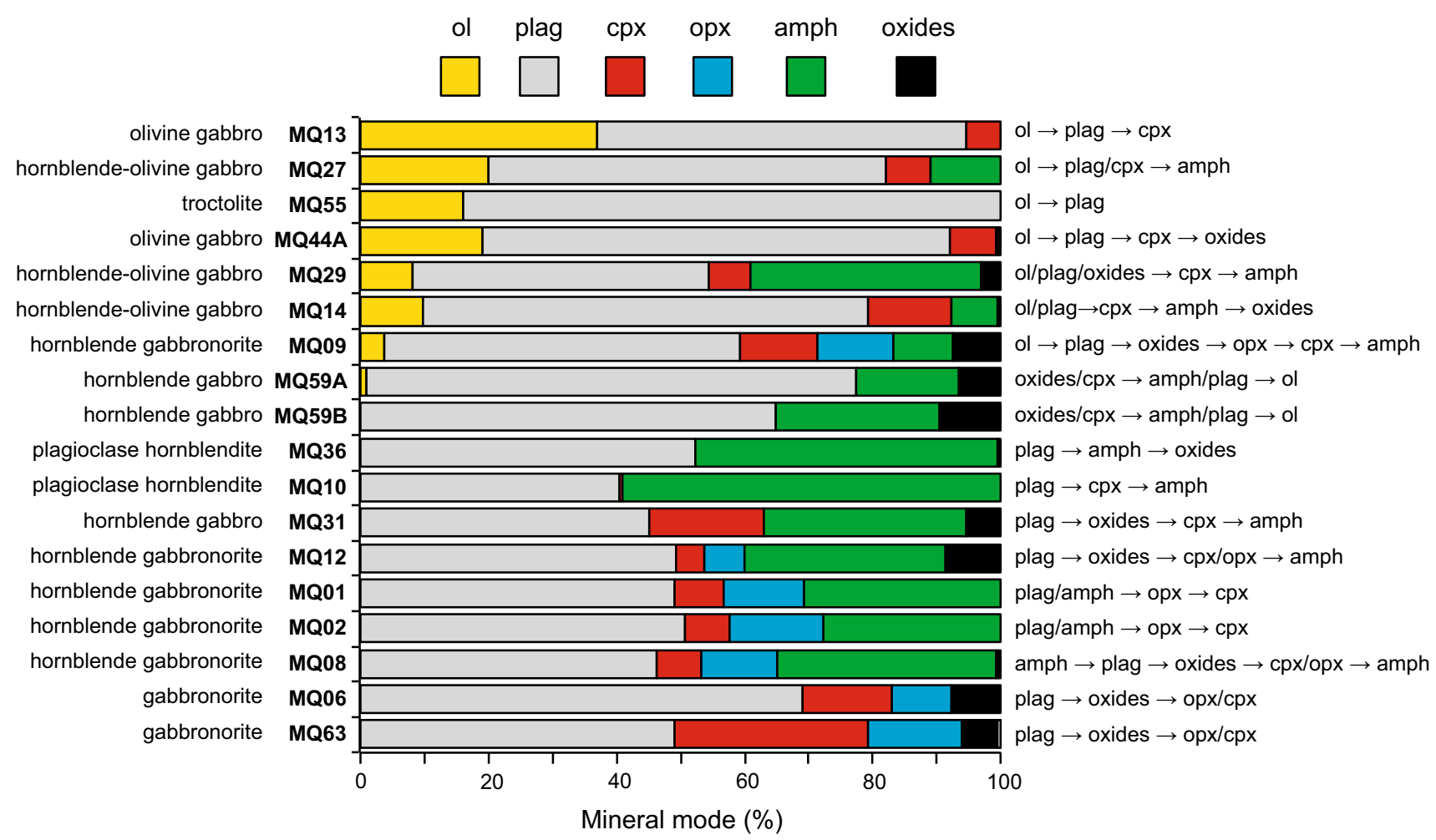

Fig. 2 Modal proportions of crystal phases within Martinique plutonic xenoliths (excluding vesiculated glass). Mineral modes were obtained through point counting of thin sections. Samples are listed from top to bottom by decreasing Fo of olivine followed by An of

Hornblende-olivine gabbros $(\mathrm{ol}+\mathrm{plag}+\mathrm{cpx}+\mathrm{amph}$ \pm opx $\pm \mathrm{spl}$ ) can be subdivided into two groups based on texture and the appearance of amphibole. One type contains large $(3 \mathrm{~mm}->1 \mathrm{~cm})$ poikilitic amphibole with clinopyroxene inclusions (Fig. 3c). The other type displays an adcumulate texture $\left(120^{\circ}\right.$ grain boundaries) with amphibole appearing interstitially and in association with clinopyroxene (Fig. 3d). Grains are $<3 \mathrm{~mm}$, and no interstitial glass is found in this type. Plagioclase $(\leq 1 \mathrm{~cm})$ is modally dominant (Fig. 2). Olivine is typically larger $(\leq 3 \mathrm{~mm})$ than in olivine gabbros and often displays weak normal Fe-Mg zoning. Plagioclase is generally unzoned, apart from one sample in which the plagioclase has reacted with the host melt, forming a normally zoned rim. Interstitial glass is present in variable proportions and contains skeletal plagioclase with similar compositions to the reacted plagioclase rims.

Hornblende gabbros (plag $+\mathrm{cpx}+\mathrm{amph} \pm \mathrm{spl}$ ) are characterised by an assemblage dominated by plagioclase and large $(3 \mathrm{~mm}->1 \mathrm{~cm})$ poikilitic amphibole with both plagioclase and clinopyroxene inclusions. Clinopyroxene ( $\leq 3 \mathrm{~mm}$ ) also contains inclusions of plagioclase (Fig. 3e). Plagioclase is unzoned apart from a number of reacted rims where in contact with interstitial glass. plagioclase. Names are based on the classification scheme of Streckeisen (1976). The crystallisation sequence (based on textural inspection) of each sample is also given

Plagioclase hornblendites (plag + amph $\pm \mathrm{cpx} \pm \mathrm{spl}$ ) are comprised of roughly equal proportions of large $(0.1-1 \mathrm{~cm})$ euhedral amphibole and smaller $(<3 \mathrm{~mm})$ plagioclase. An amphibole grain with a clinopyroxene core is found in one sample and scarce spinel is present in another. Interstitial glass $(>10 \%)$ is characteristic of the plagioclase hornblendite samples (Fig. 2f). Skeletal plagioclase microlites are found within the vesiculated glass. Plagioclase is unzoned apart from a number of reacted rims where in contact with interstitial glass.

Hornblende gabbronorites (plag + amph $+\mathrm{cpx}+\mathrm{opx}$ $\pm \mathrm{ol} \pm \mathrm{spl}$ ) are dominated by plagioclase (normally zoned in a number of samples), and orthopyroxene and clinopyroxene are present, the former in a greater proportion. Amphibole appears before or together with plagioclase in the crystallisation sequence. Larger amphibole commonly contains inclusions of clinopyroxene and orthopyroxene which may be breaking down (Fig. 3g). Portions of hornblende gabbronorite samples have a granoblastic texture. Bent plagioclase twins are present in a number of samples indicating some deformation. A number of these samples do not appear to have a cumulate origin.

Gabbronorites (plag $+\mathrm{cpx}+\mathrm{opx} \pm \mathrm{spl} \pm$ apatite) are dominated by normally zoned plagioclase and are typified 

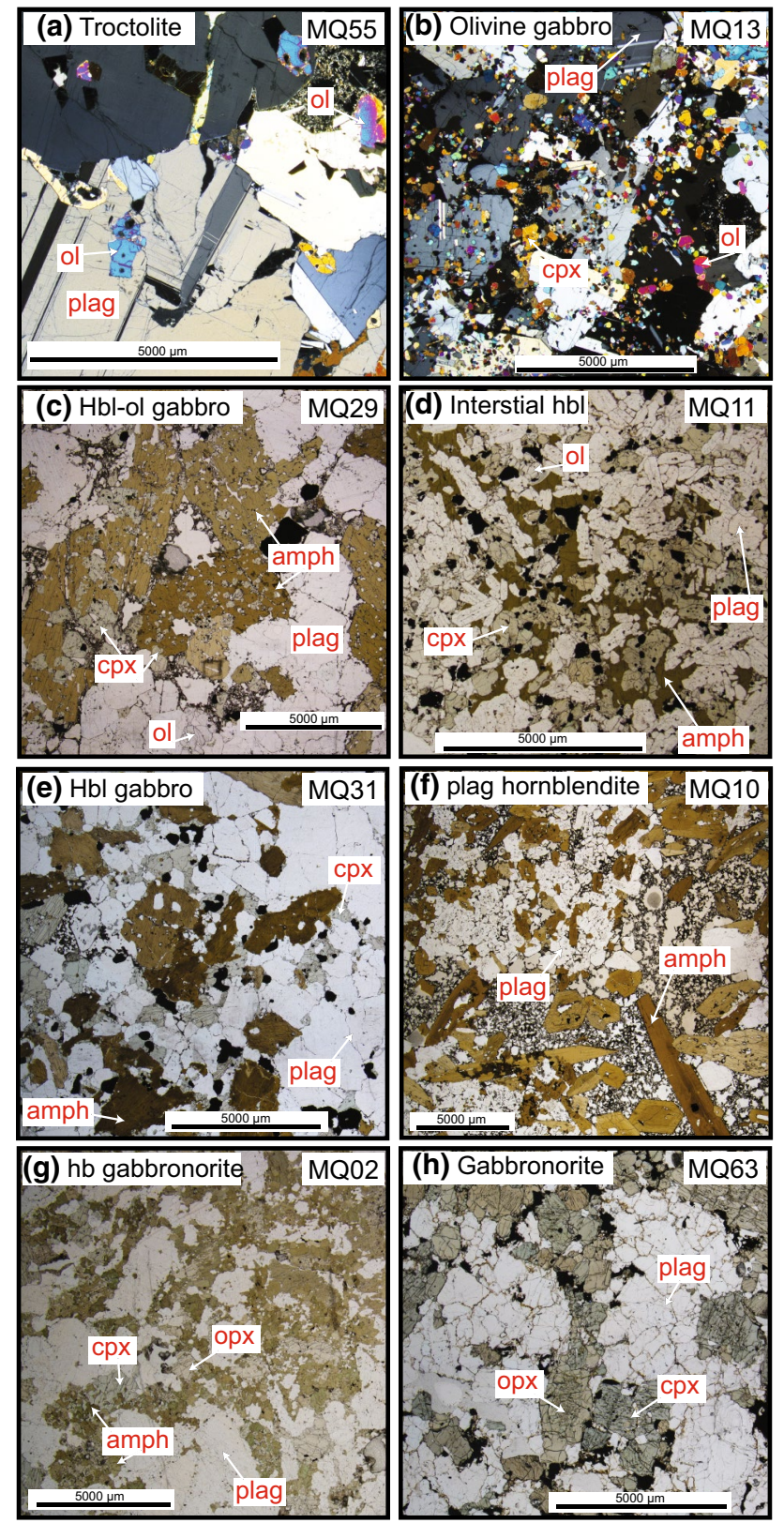

Fig. 3 Photomicrographs of plutonic xenolith types displaying characteristic textures. a Troctolite with large plagioclase and smaller olivine. Olivine in contact with interstitial glass is zoned. b Olivine gabbro with distinctive texture with large plagioclase grains with many small inclusions of olivine. c Hornblende-olivine gabbro displaying poikilitic amphibole with clinopyroxene inclusions. d Hornblendeolivine gabbro with interstitial amphibole surrounding clinopyroxene. e Hornblende gabbro with plagioclase included in clinopyroxene and amphibole. f Plagioclase hornblendite with characteristic interstitial glass. g Hornblende gabbronorite with poikilitic amphibole with clinopyroxene and orthopyroxene inclusions. $\mathbf{h}$ Gabbronorite with $120^{\circ}$ equilibrium grain boundaries. Both $\mathbf{g}$ and $\mathbf{h}$ are termed noncumulate gabbros (see text)

by the absence (or trace amounts) of amphibole (Fig. 3h). Both clinopyroxene and orthopyroxene are present, the former in a greater proportion. These samples contain both interstitial magnetite and ilmenite, which crystallised late, and large (1-mm length) needle-shaped apatite is also present. Pyroxene exsolution lamellae are present in one noncumulate gabbro sample. Bent plagioclase twins are present in a number of samples indicating some deformation. These samples do not appear to have a cumulate origin.

\section{Lava and plutonic xenolith whole-rock chemistry}

Ten crystal-rich lavas and 14 plutonic xenoliths were analysed for whole-rock major and trace element chemistry. The Martinique lavas overlap the compositions of Mt Peleé lavas analysed by Davidson and Wilson (2011). Lavas analysed in this study range from Medium-K basalts to andesites (50-63 wt $\% \mathrm{SiO}_{2}$ ). $\mathrm{CaO}$ ranges from 6 to $11 \mathrm{wt} \%, \mathrm{Na}_{2} \mathrm{O}+\mathrm{K}_{2} \mathrm{O}$ ranges from 3.2 to $4.8 \mathrm{wt} \%$ and $\mathrm{P}_{2} \mathrm{O}_{5}$ from 0.03 to $0.2 \mathrm{wt} \%$ (Fig. 4). The lavas define typical fractionation trends with decreasing $\mathrm{CaO}$ and $\mathrm{MgO}$ and increasing total alkalis with increasing $\mathrm{SiO}_{2}$ (Fig. 4). $\mathrm{P}_{2} \mathrm{O}_{5}$ positively trends with $\mathrm{SiO}_{2}$, but with some scatter in lavas, and there is no fractionation peak to indicate apatite saturation (Fig. 4). Lavas display typical island arc trace element patterns with enrichment in LILE (Fig. 5a). Chondritenormalised REE patterns have a concave-up shape, consistent with the removal of amphibole, which is relatively enriched in MREE over HREE (concave-down REE pattern; Fig. 5b). Lava samples display greater enrichments in incompatible elements $(\mathrm{Cs}, \mathrm{U}, \mathrm{Th}, \mathrm{Pb}, \mathrm{Rb}$ and $\mathrm{Ba})$ than their plutonic counterparts (Fig. 5a).

The whole-rock chemistry of the plutonic xenoliths is a direct reflection of their crystal assemblage and the majority of compositions of the analysed samples are consistent with a cumulate origin. However, three of the analysed gabbroic xenoliths have chemistries closer to lava compositions and therefore we have termed these non-cumulate gabbros (Fig. 4). The plutonic xenoliths lie outside the field defined by the lavas on major element plots and do not follow a liquid line of descent (Fig. 4). Plutonic xenoliths have higher $\mathrm{CaO}(>12 \mathrm{wt} \%)$ and $\mathrm{MgO}(>5 \mathrm{wt} \%)$ and lower $\mathrm{Na}_{2} \mathrm{O}+\mathrm{K}_{2} \mathrm{O}(<3 \mathrm{wt} \%)$ and $\mathrm{P}_{2} \mathrm{O}_{5}(<0.05 \mathrm{wt} \%)$ to lavas (Fig. 4). In contrast to lavas, trace element spidergrams reveal plutonic xenoliths have a stronger positive $\mathrm{Sr}$ anomaly, and have positive $\mathrm{Ti}$ anomalies (Fig. 5a). Amphibolerich xenoliths and samples in which amphibole has crystallised early have concave-down chondrite-normalised REE patterns and lack Eu anomalies (Fig. 5b). Xenoliths which are amphibole free, or in which amphibole has crystallised late, have positive Eu anomalies, reflecting the high modal proportions of plagioclase (Fig. 2).

The amphibole-bearing plutonic xenoliths have higher Dy/Yb ratios $(\sim 1.8-2.2)$ and lower La $(0-7 \mathrm{ppm})$ than lavas (Dy/Yb 1.4-1.7, La 6-14 ppm) (Fig. 6). However, a subset of gabbroic (non-cumulate) samples have similar 
Fig. 4 Whole-rock major element chemistry of Martinique cumulates and lavas from this study and Davidson and Wilson (2011)

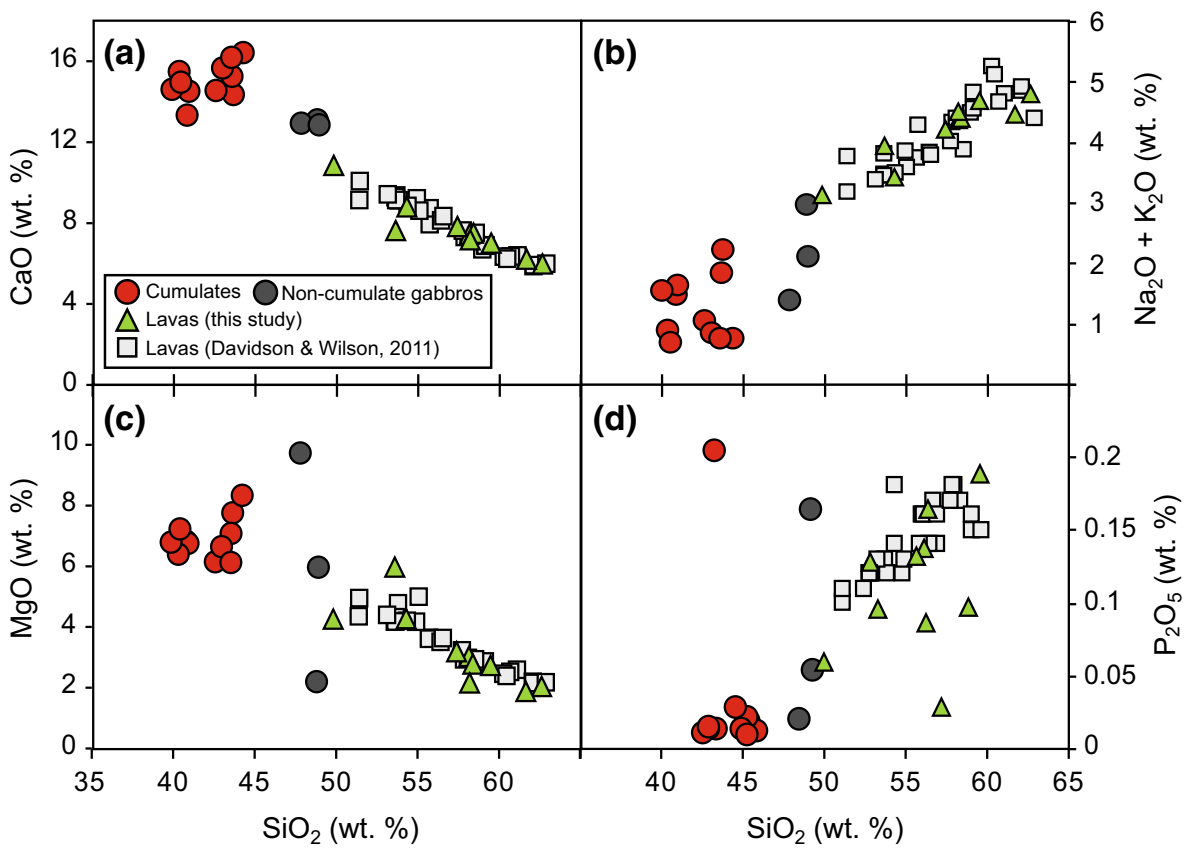

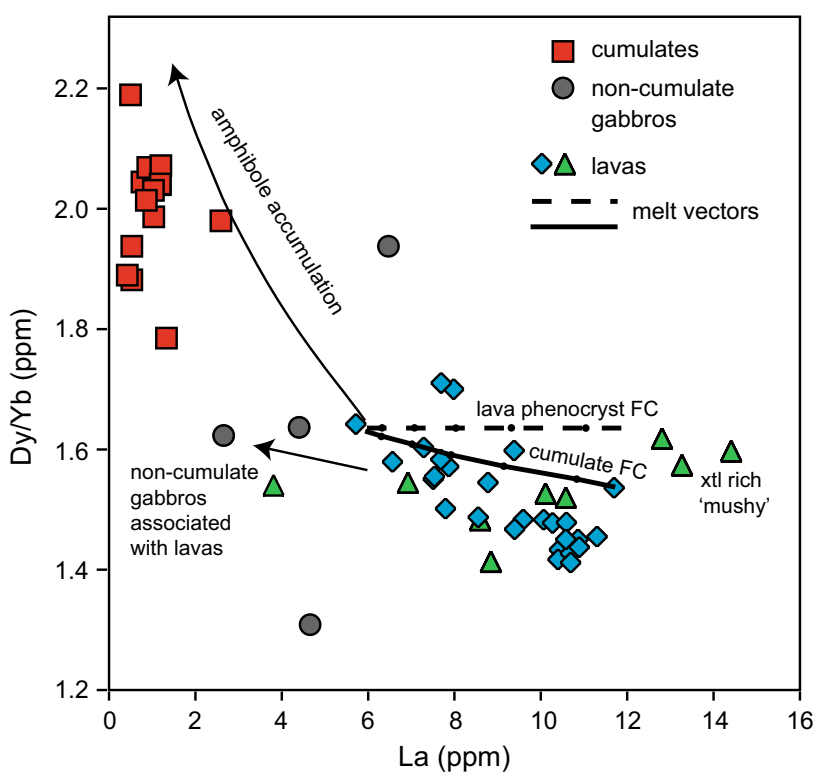

Fig. 6 Whole-rock La versus $\mathrm{Dy} / \mathrm{Yb}$ of Martinique lavas and plutonic xenoliths. Solid and dashed lines are modelled melt vectors from the fractional crystallisation of either the lava phenocryst or the cumulate assemblage (after Davidson and Wilson 2011)

$\mathrm{Dy} / \mathrm{Yb}$ to lavas $(\sim 1.3-1.9)$. The non-cumulate gabbros are either hornblende gabbronorites or gabbronorites. Minerals from these samples also have distinctive chemistries (discussed below), suggestive of a different origin to the cumulate plutonic xenolith samples.
Fig. 5 a Extended whole-rock trace element spidergram and b REE diagram of Martinique lavas (data from Davidson and Wilson (2011) and this study) and plutonic xenoliths, normalised to primitive mantle (Palme and O'Neill 2003) 


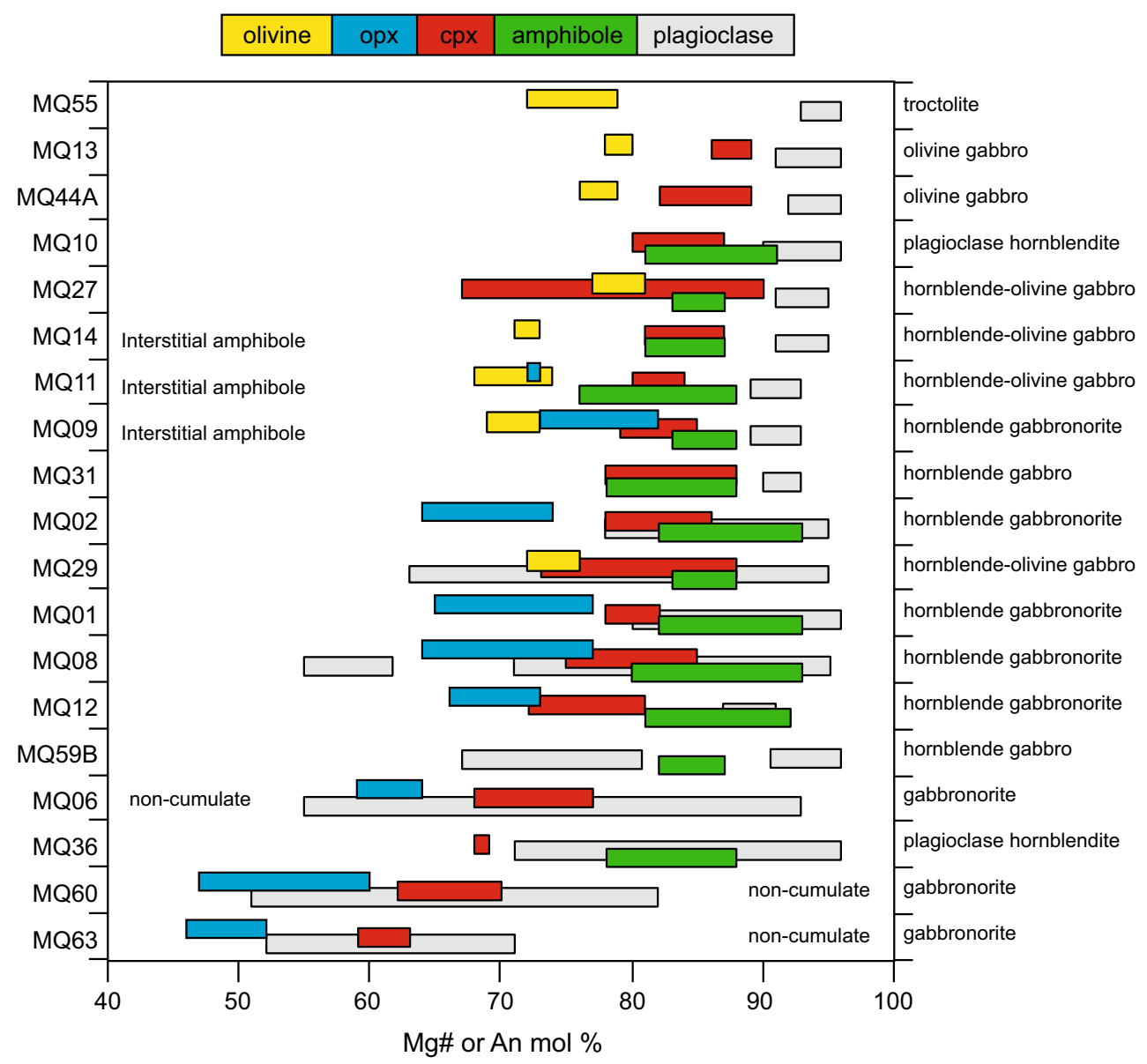

Fig. 7 Summary of phase compositions for the range of studied plutonic xenolith types: $\mathrm{Mg} \#\left(100 \mathrm{Mg} /\left(\mathrm{Mg}+\mathrm{Fe}^{2+}\right)\right.$ of olivine, orthopyroxene, clinopyroxene, amphibole, and An (mol\%) of plagioclase. Samples are ordered based on the mean clinopyroxene Mg\#

\section{Mineral major and trace element chemistry}

Here, the in situ major and trace element concentrations of olivine, plagioclase, amphibole, clinopyroxene, orthopyroxene and spinel are summarised. The range in $\mathrm{Mg}$ number of olivine, opx, cpx and amphibole, and the An (mol\%) of plagioclase are summarised in Fig. 7. The full dataset is presented in Online Resource 1.

\section{Olivine}

Olivine is present in $<50 \%$ of studied samples and has a relatively narrow range in composition $\left(\mathrm{Fo}_{81-68}\right)$ (Fig. 8). The olivine is pristine with no signs of alteration to iddingsite or serpentine, in marked contrast to Grenada (Stamper et al. 2014). $\mathrm{CaO}$ contents are $<0.25 \mathrm{wt} \%$ and $\mathrm{Ni}$ contents are low (40-750 ppm) (Fig. 8). Ni contents are similar to those from St. Vincent (40-720 ppm; Tollan et al. 2012), but significantly lower than cumulates from Grenada which range from 0-0.3 wt\% (Stamper et al. 2014). The $\mathrm{CaO}$ content varies with sample type from an average of $0.1 \mathrm{wt} \%$ in hornblende gabbronorites to $0.2 \mathrm{wt} \%$ in olivine gabbros (Fig. 8a). The majority of olivine is unzoned; however, when in contact with interstitial glass, a number of grains display normal zoning (lower Fo rims) reflecting reaction with interstitial melt. Transition metals are the only group of trace elements with significant abundances (32007600 ppm Mn, 136-390 ppm Zn, 226-336 ppm Co). Mn and $\mathrm{Zn}$ concentrations increase with decreasing Fo, but no clear trend is shown by Co.

\section{Plagioclase}

Plagioclase is modally dominant in all studied samples (Fig. 2) and is, in general, anorthite-rich ( $\mathrm{An}_{96-70}$; Fig. 7). Those analyses of plagioclase $<\mathrm{An}_{80}$ are from plagioclase rims, which are often in contact with interstitial glass, and therefore represent a reacted rim. In the majority of samples, the interiors of plagioclase are unzoned, apart from in gabbronorites in which it is oscillatory zoned. Oscillatory zoned plagioclase is also present within Martinique lavas (Pichavant et al. 2002; Davidson and Wilson 2011). The 

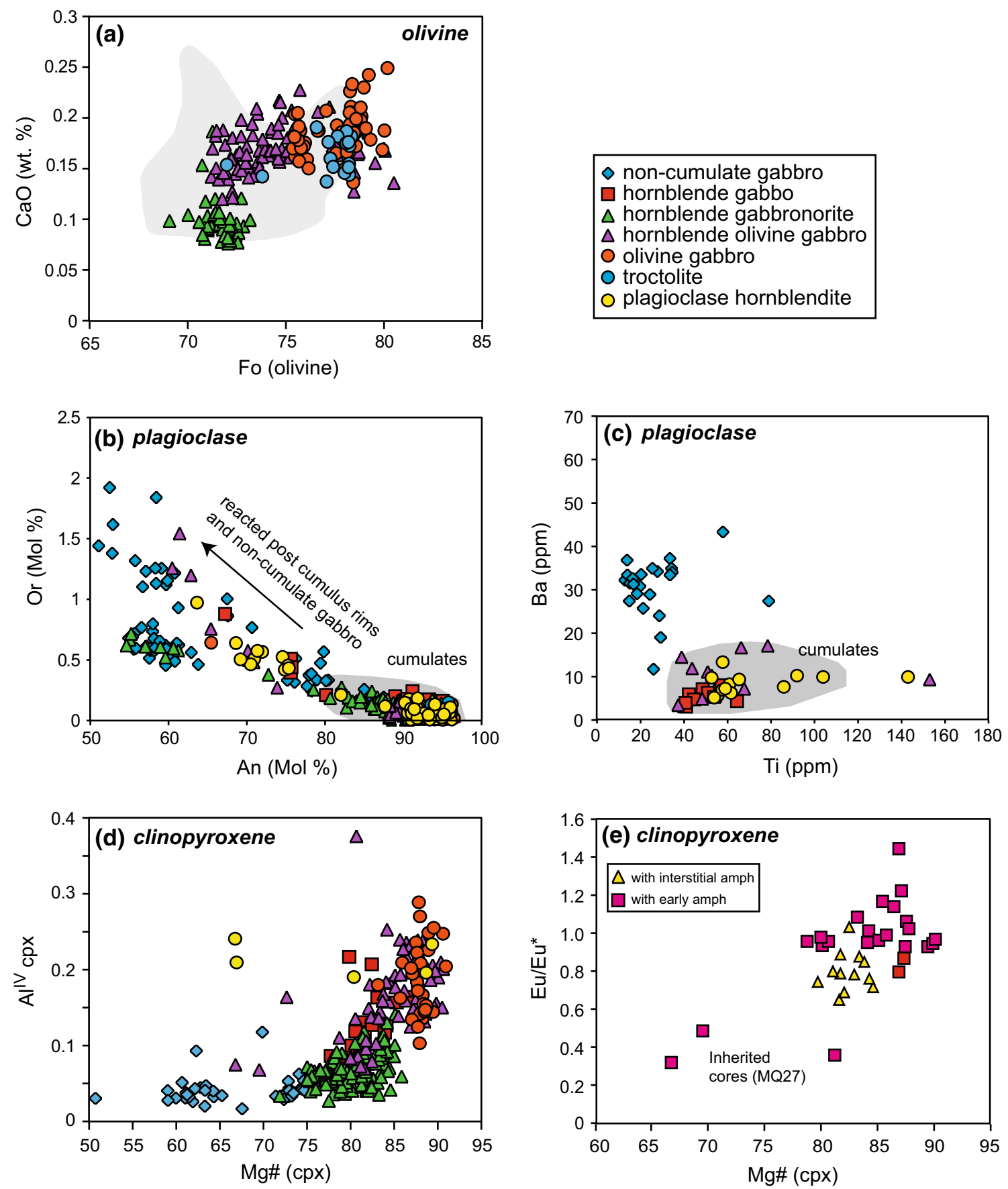

Fig. 8 a Olivine Fo versus $\mathrm{CaO}(\mathrm{wt} \%)$ from different plutonic xenolith types. Grey shaded area represents range covered by Grenada cumulates (Stamper et al. 2014). b Major and c trace element chemistry of plagioclase from different plutonic xenolith types. Grey shaded

range of plagioclase compositions within the gabbronorite samples is greater and more sodic $\left(\mathrm{An}_{93-51}\right)$ and covers a similar range to zoned plagioclase within Martinique lavas which have calcic cores $\mathrm{An}_{85-90}$ and sodic rims $\mathrm{An}_{50-65}$ (Pichavant et al. 2002; Fig. 8b).

areas represent the compositional range covered by plutonic xenoliths with a cumulate origin. d Major element variations of clinopyroxene from different plutonic xenolith types. e $\mathrm{Mg \#}$ versus $\mathrm{Eu} / \mathrm{Eu}^{*}$ of clinopyroxene from samples with either early or interstitial amphibole

Plagioclase displays typical REE characteristics of a relative LREE/HREE enrichment and a positive Eu anomaly. $\mathrm{Sr}$ concentrations are higher in an olivine gabbro sample (900-1300 ppm) compared with a range of 300-550 ppm in other sample types. $\mathrm{Sr}$ and $\mathrm{Ba}$ concentrations do not 


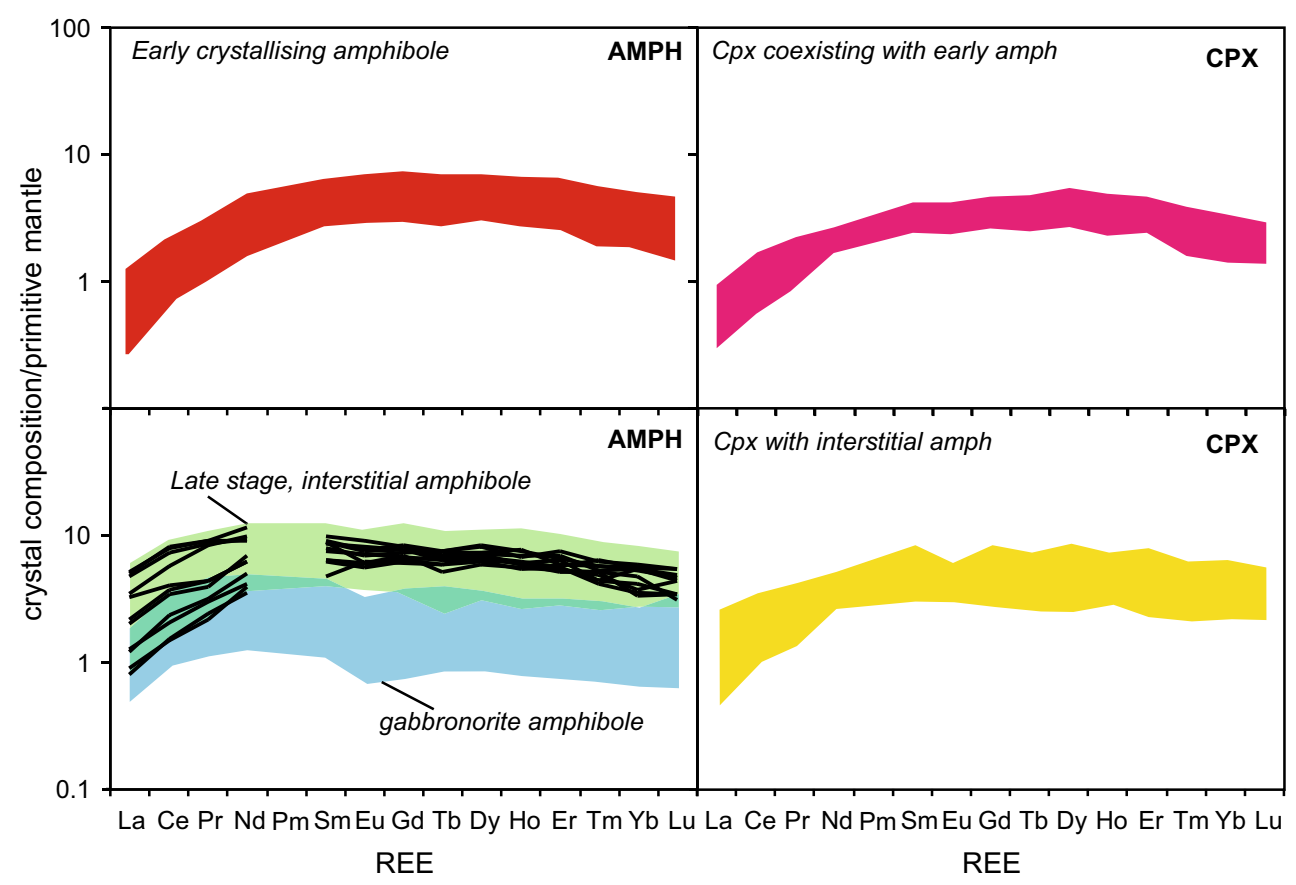

Fig. 9 REE patterns of amphibole and clinopyroxene types normalised to primitive mantle values (Palme and O'Neill 2003). Black lines within the shaded area of late-stage, interstitial amphibole are the REE in one sample to show the variation in LREE

show systematic variations with $\mathrm{An}$. Ba is enriched in plagioclase from gabbronorites (11-43 ppm) compared with other sample types (3-20 ppm) (Fig. 8c). Ti (13-154 ppm) and $\mathrm{Mn}$ concentrations (18-100 ppm) are highest in olivine gabbros and lowest within gabbronorites in which spinel has crystallised before plagioclase (Fig. 8c).

\section{Clinopyroxene}

Clinopyroxene is present in all samples, with the exception of one troctolite. Compositions are $\mathrm{Ca}-, \mathrm{Al}-$ and $\mathrm{Fe}^{3+/} \Sigma \mathrm{Fe}$ rich diopsides with $\mathrm{Mg} \# 90-67 . \mathrm{Fe}^{3+/} \Sigma \mathrm{Fe}$, determined through stoichiometry, ranges from $0.0-0.6$ and decreases

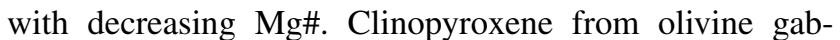
bros and hornblende-olivine gabbros the most enriched in $\mathrm{Fe}^{3+}$. Gabbronorite samples have lower $\mathrm{Mg}$ compositions (Mg\# 77-59) (Fig. 8d). Grains are either unzoned or have patchy sector zoning. There is a large variation in the concentration of $\mathrm{Al}_{2} \mathrm{O}_{3}$; clinopyroxene from olivine gabbros and hornblende gabbros are enriched (2.5-9.0 wt $\% \mathrm{Al}_{2} \mathrm{O}_{3}$ ) compared with those from gabbronorites (1.0-4.3 wt\% $\mathrm{Al}_{2} \mathrm{O}_{3}$ ). This is reflected in $\mathrm{Al}^{\mathrm{IV}}$, with a range in olivine gabbros and hornblende gabbros of $\mathrm{Al}^{\mathrm{IV}} 0.1-0.3$, compared to $\mathrm{Al}^{\mathrm{IV}}<0.1$ in gabbronorites (Fig. $8 \mathrm{~d}$ ).

The trace element concentrations of clinopyroxene vary with sample type and whether amphibole crystallised early or late in the sequence. Clinopyroxene associated with interstitial amphibole have small $\mathrm{Eu} / \mathrm{Eu}^{*} \sim 0.85$, whereas clinopyroxene associated with early crystallising amphibole does not display an Eu anomaly. Within one olivine gabbro sample (MQ27), a number of clinopyroxene cores have a strong negative $\mathrm{Eu} / \mathrm{Eu}^{*}$ of $\sim 0.4$ with $\mathrm{Mg} \#$ 67-82; however, the rims of these grains do not have a Eu anomaly and have higher Mg\# (80-90; Fig. 8e).

Clinopyroxene displays a large range in incompatible trace elements, highlighted by the range shown by Hf and $\mathrm{Zr}$ (Online Resource 2). Grains from samples containing early crystallising amphibole have lower concentrations of incompatible trace elements than grains associated with late crystallising amphibole. The full range in clinopyroxene $\mathrm{Hf}$ and $\mathrm{Zr}$ from each type is covered by a single plutonic xenolith sample. All clinopyroxene has enrichments in MREE and HREE compared to LREE (Fig. 9). In samples with early crystallising amphibole, the clinopyroxene REE patterns have a humped profile compared to a flatter profile in samples containing late crystallising amphibole (Fig. 9). There is a greater variation in the LREE concentrations of clinopyroxene associated with late amphibole (La/ $\mathrm{Yb}$ of $0.17-1.56)$ compared to grains in samples in which amphibole crystallised early $(\mathrm{La} / \mathrm{Yb}$ of $0.13-0.7)$.

\section{Orthopyroxene}

Orthopyroxene is present in $\sim 50 \%$ of the studied samples and only occurs in assemblages in which clinopyroxene is present. Compositions range from $\mathrm{Mg} \#$ 64-82 (Fig. 7) and 
$\mathrm{En}_{75-60}$ (Online Resource 3) in amphibole-bearing cumulate samples. Orthopyroxene in amphibole free, and noncumulate gabbros are less magnesian (Mg\# 64-46 and $\left.\mathrm{En}_{60-44}\right)$. Exsolution lamelle contained in one sample is more calcic $\left(>\mathrm{Wo}_{4}\right)$. Nickle concentrations are lower and $\mathrm{Ti}$ concentrations are higher in olivine-bearing gabbros (Ni 10-30 ppm, Ti 840-1670 ppm) compared with olivine free gabbros (Ni 95-202 ppm, Ti 440-1030 ppm; Online Resource 3). Zinc (290-400 ppm) and V (45-160 ppm) are consistent between sample types and do not vary systematically with major element concentrations.

\section{Amphibole}

Amphibole compositions based on Leake et al. (2003) vary between sample types; magnesio-hastingsite is the dominant type in hornblende-olivine gabbros and hornblende gabbros; tschermakite-pargasite is common in hornblende gabbonorites and magnesio-hornblende in gabbronorites. Compositions cover a narrow range in regard to $\mathrm{Mg \#} \mathrm{(93-}$ 78; Fig. 7), but a large range in $\mathrm{Al}\left(\mathrm{Al}^{\mathrm{IV}} 0.88-2.25\right)$ with euhedral, early crystallising amphibole more aluminiumrich than interstitial and poikilitic amphibole (Fig. 10). $\mathrm{Na}+\mathrm{K}^{\mathrm{A}}$ ranges from $0.04-0.76$ and positively correlates (slope $=0.51$ ) with $\mathrm{Al}^{\mathrm{IV}}$ indicating temperature-sensitive edenite exchange is significant (Fig. 10a). $\mathrm{Ca}^{\mathrm{B}}$ versus $\mathrm{Al}^{\mathrm{IV}}$ indicates that plagioclase exchange is significant in amphibole from the majority of plutonic xenoliths (Fig. 10b). However, plagioclase exchange is insignificant in amphiboles from hornblende gabbronorite samples, in which amphibole crystallised before plagioclase. $\mathrm{Al}^{\mathrm{IV}}$ versus $\mathrm{Al}^{\mathrm{VI}}$ indicates the extent of the pressure sensitive Al-Tschermack substitution (Fig. 10c). There is no trend in $\mathrm{Al}^{\mathrm{IV}}$ versus $\mathrm{Al}^{\mathrm{VI}}$ within each xenolith type, with the exception of non-cumulate gabbro. However, differences in $\mathrm{Al}^{\mathrm{IV}}$ and $\mathrm{Al}^{\mathrm{VI}}$ between xenolith types may suggest a relative shift in crystallisation pressures.

Within Martinique plutonic xenoliths, late-stage, interstitial amphibole appears to be texturally associated with clinopyroxene, and this observation is reflected in the trace element chemistry of amphibole. Like clinopyroxene, amphibole shows a large variation in incompatible trace elements, highlighted by the range shown by $\mathrm{Hf}$ and $\mathrm{Zr}$, which span an order of magnitude (Online Resource 2). Early amphibole has lower concentrations of incompatible trace elements (Hf, $\mathrm{Zr}, \mathrm{Zn}$ ) compared with interstitial amphibole, and the ratios between incompatible trace elements are not consistent across amphibole types (i.e. different slopes on Hf versus $\mathrm{Zr}$ plot [Online Resource 2]). Interstitial amphibole is more enriched and has a larger range in LREE (and Ba) compared with early amphibole (Fig. 10). This is particularly evident in amphibole from an olivine gabbro sample (MQ14), which displays a fivefold variation in La (Fig. 9). Amphibole that has crystallised early displays concave-down or 'humped' REE profile, with a MREE/HREE enrichment and a significant LREE depletion. In contrast, interstitial amphibole has flatter REE profiles, with less depletion in LREE and only moderate MREE/HREE fractionation (Fig. 12). It is important to note that neither the early or late crystallising amphibole display a negative Eu anomaly. The amphibole REE profiles have very similar shape to those of the associated clinopyroxene within sample types (Fig. 9). This suggests the amphibole may have formed from the breakdown of clinopyroxene, a reaction that is explored further within the discussion section.

\section{Spinel}

Spinel is present in $>50 \%$ of studied samples. There are two distinctive spinel compositions present, depending on the presence of coexisting ilmenite (Online Resource 4). Coexisting magnetite and ilmenite are present within the three non-cumulate gabbronorites, and these have a higher $\mathrm{TiO}_{2}$, lower $\mathrm{Al}_{2} \mathrm{O}_{3}$ magnetite present. Within the amphibole-bearing cumulate gabbros, only a single-phase, an Alrich magnetite is present in each sample.

\section{Discussion}

\section{Mineral chemistry}

There is a marked contrast between the composition of plagioclase (high anorthite) and coexisting (low Fo) olivine within Martinique plutonic xenoliths, which is a common feature of plutonic rocks from both the Lesser Antilles and global arc settings (Online Resource 5). Generally, this is attributed to high $\mathrm{H}_{2} \mathrm{O}$ contents, which suppresses plagioclase crystallization until the fractionation of mafic phases has substantially depleted the melt in $\mathrm{MgO}$. However, in plutonic xenoliths from Martinique, plagioclase is a ubiquitous phase and commonly crystallises before clinopyroxene and amphibole. In addition, the coexisting compositions have not been reproduced by experimental studies performed on appropriate melt compositions (Sisson and Grove 1993a; Pichavant and Macdonald 2007). A two-stage polybaric differentiation could account for the observed plagioclase and olivine compositions, as suggested for the evolution of St. Vincent magmas (Melekhova et al. 2015). In this case, the olivine-bearing samples have crystallised from differentiated basaltic andesite magmas, rather than as residual assemblages from deep crustal source regions, where the melts were generated (Melekhova et al. 2015). Olivines from Martinique have relatively low $\mathrm{Fo}$ and $\mathrm{Ni}$ contents, providing evidence of crystallisation from a melt 

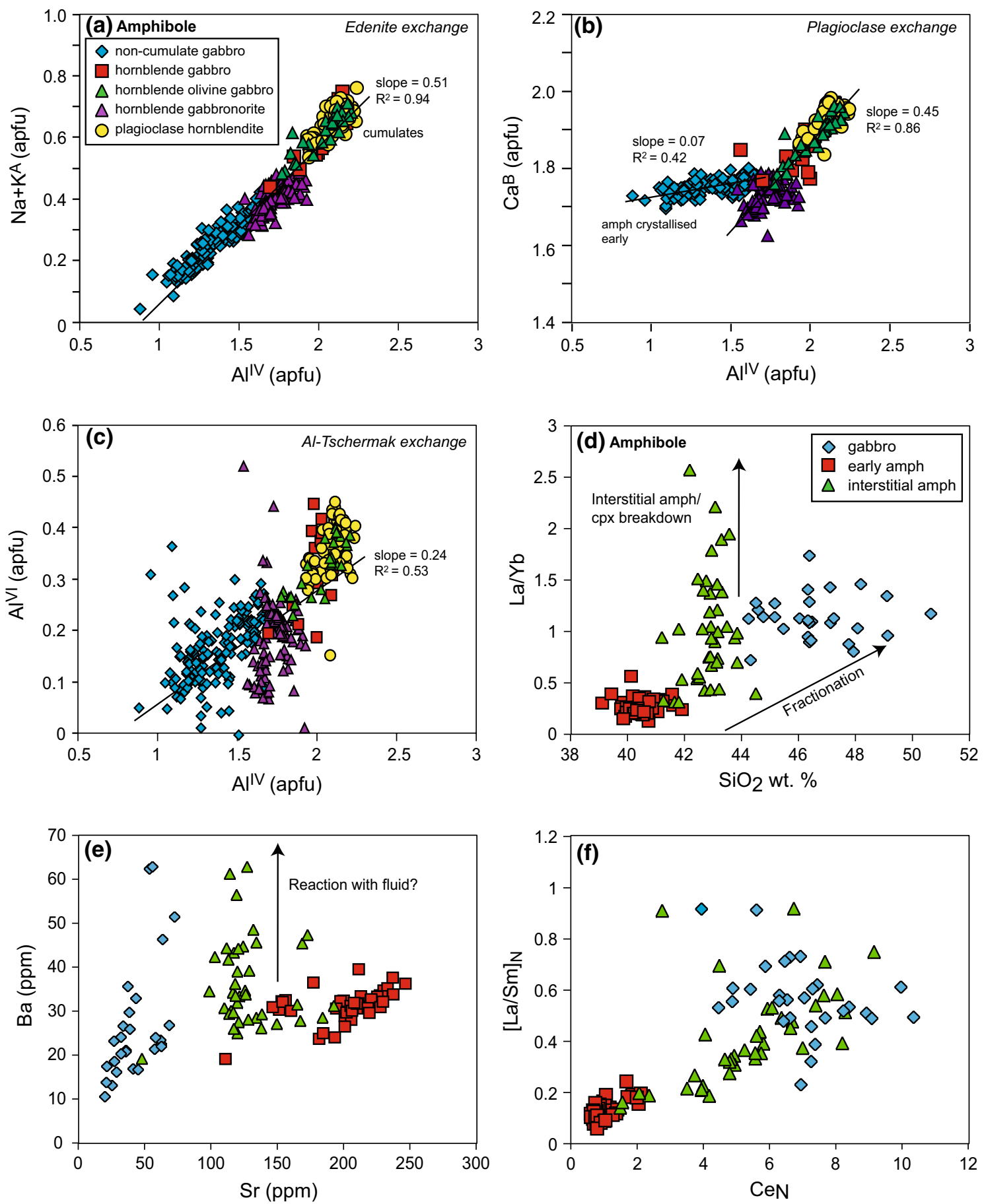

Fig. 10 Major and trace element variations of amphibole. Structural components (Leake et al. 1997) are used to show variation in major elements and a edenite, b plagioclase and $\mathbf{c}$ Al-Tschermak exchange.

that has undergone prior olivine fractionation and is consistent with early differentiation in the deep crust.

There is a clear distinction in the major and trace element chemistry of crystal phases between plutonic xenolith types. It is possible to distinguish whether a sample is of cumulate origin by using the compositions of crystal

The trace element variations of early, interstitial and non-cumulate gabbro amphibole (d-f) highlight enrichments in LREE and fluid mobile elements within interstitial amphibole

phases, and these support the textural evidence and wholerock compositions. In general, non-cumulate gabbros contain crystals with a larger range and more evolved compositions than cumulate equivalents. Non-cumulate gabbros include both gabbronorite and hornblende gabbronorite assemblages which represent 'frozen' portions of a melt. 
Table 1 Comparison of appropriate experimental studies which return assemblages and compositions close to that of the natural plutonic xenolith samples

\begin{tabular}{|c|c|c|c|c|c|c|}
\hline & Experiment & Compositions & & Temperature & Pressure & $\mathrm{H}_{2} \mathrm{O}$ \\
\hline \multirow[t]{2}{*}{ Troctolite/olivine gabbro } & $\begin{array}{l}\text { Sisson and Grove (1993b)_Low } \\
\text { Mg-high Al basalt }\end{array}$ & Olivine Fo $72-80$ & $\mathrm{Cpx} \sim 0.1 \mathrm{Al}^{\mathrm{IV}}$ & $1020-1082{ }^{\circ} \mathrm{C}$ & $0.1 \mathrm{GPa}$ & Saturated \\
\hline & $\begin{array}{l}\text { Pichavant and MacDonald } \\
\text { (2007)_High Al basalt }\end{array}$ & Olivine Fo $75-82$ & $\mathrm{Cpx} \sim 0.2 \mathrm{Al}^{\mathrm{IV}}$ & $1050-1150{ }^{\circ} \mathrm{C}$ & $0.4 \mathrm{GPa}$ & $1.7-5.9 \mathrm{wt} \%$ \\
\hline Plagioclase hornblendite & $\begin{array}{l}\text { Pichavant et al. (2002)—Basaltic } \\
\text { andesite }\end{array}$ & Plag An 75-90 & $\mathrm{Hbl} \sim 1.7 \mathrm{Al}^{\mathrm{IV}}$ & $945-949^{\circ} \mathrm{C}$ & $0.4 \mathrm{GPa}$ & $8.2 \mathrm{wt} \%$ \\
\hline \multirow[t]{3}{*}{ Hornblende gabbro } & $\begin{array}{l}\text { Pichavant et al. (2002)_-Basaltic } \\
\text { andesite }\end{array}$ & $\begin{array}{l}\text { Olivine Fo } 70 \\
\text { Plag An } 85\end{array}$ & $\begin{array}{l}\mathrm{Hbl} \sim 1.8 \mathrm{Al}^{\mathrm{IV}} \\
\mathrm{Cpx} \sim 0.15 \mathrm{Al}^{\mathrm{IV}}\end{array}$ & $1000^{\circ} \mathrm{C}$ & $0.4 \mathrm{GPa}$ & $6.8 \mathrm{wt} \%$ \\
\hline & $\begin{array}{l}\text { Sisson and Grove (1993b)_High } \\
\text { Al basalt }\end{array}$ & $\begin{array}{l}\text { Olivine Fo } 77 \\
\text { Plag An } 85\end{array}$ & $\begin{array}{l}\mathrm{Hbl} \sim 1.8 \mathrm{Al}^{\mathrm{IV}} \\
\mathrm{Cpx} \sim 0.23 \mathrm{Al}^{\mathrm{IV}}\end{array}$ & $965{ }^{\circ} \mathrm{C}$ & $0.2 \mathrm{GPa}$ & Saturated \\
\hline & Martel et al. (1999)—Andesite & Plag An 82 & $\begin{array}{l}\mathrm{Hbl} \sim 1.45 \mathrm{Al}^{\mathrm{IV}} \\
\mathrm{Cpx} \sim 0.08 \mathrm{Al}^{\mathrm{IV}}\end{array}$ & $930^{\circ} \mathrm{C}$ & $0.2 \mathrm{GPa}$ & $6.9 \mathrm{wt} \%$ \\
\hline \multirow[t]{2}{*}{ (Hornblende) gabbronorite } & $\begin{array}{l}\text { Pichavant et al. (2002)—Basaltic } \\
\text { Andesite }\end{array}$ & Plag An 62-71 & $\begin{array}{l}\text { Cpx En } 35-54 \\
\text { Opx En 54-82 }\end{array}$ & $950-1016^{\circ} \mathrm{C}$ & $0.4 \mathrm{GPa}$ & $3.9-6.9 \mathrm{wt} \%$ \\
\hline & $\begin{array}{l}\text { Melekhova et al. (2015)_-High } \\
\text { MgO basalt }\end{array}$ & $\begin{array}{l}\text { Plag An } 47-81 \\
\text { Hbl } 1.75-2.1 \mathrm{Al}^{\mathrm{IV}}\end{array}$ & $\begin{array}{l}\text { Cpx En } 44-46 \\
\text { Opx En } 77-86\end{array}$ & $950-1230{ }^{\circ} \mathrm{C}$ & $0.7-1 \mathrm{GPa}$ & $0.6-2.3 \mathrm{wt} \%$ \\
\hline
\end{tabular}

Plagioclase within non-cumulate gabbros are oscillatory zoned and cover a similar range in compositions to phenocrysts within erupted lavas (Pichavant et al. 2002). There is a distinctive group of low An and Or (mol\%) plagioclase compositions which lie off the main trend of the cumulate plagioclase (Fig. 8). This group corresponds to plagioclase rims within a number of non-cumulate gabbro samples and likely represents crystallisation after post-cumulus interaction with their host lavas. Similarly contrasting chemistries between cumulate and non-cumulate gabbros are observed in both clinopyroxene and orthopyroxne (Fig. 8 and Online Resource 3).

\section{Intensive variables and the origin of plutonic xenoliths}

Determining the storage conditions $\left(P-T-\mathrm{H}_{2} \mathrm{O}-f \mathrm{O}_{2}\right)$ under which Martinique plutonic xenoliths were formed is essential in understanding the sub-volcanic system beneath Martinique and the evolution of Martinique eruption products. However, constraining reliable estimates of Martinique storage conditions remains challenging for the available plutonic assemblages, and the number of techniques that can be used is limited. Here we use a combination of geothermometers (Putirka 2016; Ridolfi and Renzulli 2012; Holland and Blundy 1994; Ghiorso and Evans 2008) and compare the results with the run conditions of appropriate experimental studies (approach of Stamper et al. 2014; Table 1).

Experimental studies were chosen if their starting compositions fall on the liquid line of descent, if they reproduce the plutonic types represented in Martinique, and if the phase compositions are close to that of the natural samples
(Online Resource 6; Table 1). If experimental crystal compositions reproduce those from natural assemblages, the temperature, pressure and water content can then be inferred from the experimental run conditions. Experiments by Sisson and Grove (1993a) and Pichavant and MacDonald (2007) suggest shallow olivine gabbro crystallisation (0.1-0.4 GPa) at $1020-1150{ }^{\circ} \mathrm{C}$ and high water contents (saturated and 1.7-5.9 wt\%, respectively). Pichavant et al. (2002) experiments suggest plagioclase hornblendite crystallisation at $0.4 \mathrm{GPa}, 945-949{ }^{\circ} \mathrm{C}$ and high water contents (8.2 wt\%). Sisson and Grove (1993a) and Pichavant et al. (2002) experiments suggest hornblende gabbro crystallisation at $0.2-0.4 \mathrm{GPa}, 965-1000{ }^{\circ} \mathrm{C}$ and high water contents (saturated and $6.8 \mathrm{wt} \%$, respectively). We therefore infer a common origin to plagioclase hornblendite and hornblende gabbro assemblages. Experiments by Pichavant et al. (2002) and suggest gabbronorite crystallisation at 0.4 $\mathrm{GPa}, 950-1016{ }^{\circ} \mathrm{C}$ and water contents from 3.9-6.9 wt\% $\mathrm{H}_{2} \mathrm{O}$. Experiments by Melekhova et al. (2015) were run at higher pressures $(0.7-1 \mathrm{GPa})$ and lower water contents (0.6-2.3 wt\%) and the composition of phases were not as close to natural samples as Pichavant et al. (2002) (Online Resource 6).

Model temperature and oxygen fugacity estimates were made using amphibole only geothermometer of Ridolfi and Renzulli (2012) and Putirka (2016). Within Martinique xenoliths, interstitial amphibole is not in textural equilibrium with the cumulate phases, and there is no associated interstitial melt available to test for chemical equilibrium. It has also been shown that $\mathrm{H}_{2} \mathrm{O}$-rich magmas, which will be relatively $\mathrm{Al}_{2} \mathrm{O}_{3}$-rich, will overestimate crystallisation temperatures (Erdmann et al. 2014). Therefore, 


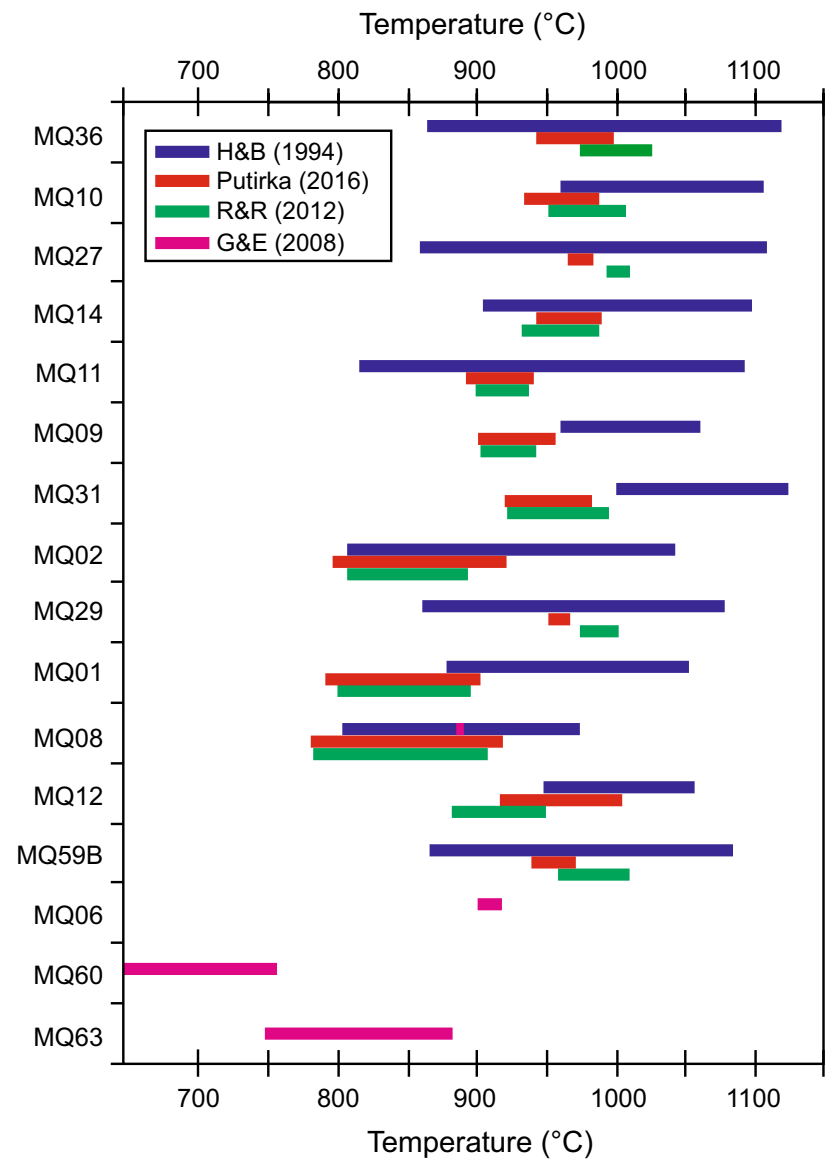

Fig. 11 Comparison of temperature estimates using the hornblendeplagioclase model of Holland and Blundy (1994) and the amphibole only models of Ridolfi and Renzulli (2012) and Putirka (2016). In non-cumulate gabbro samples, which contained coexisting magnetite and ilmenite, the Fe-Ti oxide model of Ghiorso and Evans (2008) was used

amphibole only model temperatures need to be used with caution. However, the model temperatures in amphibolebearing samples are within the range of those inferred from experimental studies. Amphiboles in cumulates using Ridolfi and Renzulli (2012) return model temperatures of $880-1020{ }^{\circ} \mathrm{C}$, but are lower within non-cumulate gabbros $780-920{ }^{\circ} \mathrm{C}$ (Online Resource 7; Fig. 11). Oxygen fugacity estimates using Ridolfi and Renzulli (2012) are 0.6-3.4 $\triangle \mathrm{NNO}$ and vary between samples (Online Resource 7). Oxygen fugacity estimates of Ghiorso and Evans (2008) of gabbronorite samples (both magnetite and ilmenite present) are -0.2 to $0.8 \Delta \mathrm{NNO}$. Model temperatures using the pressure independent model (Eq. 5) of Putirka (2016) cover a range of $890-1005{ }^{\circ} \mathrm{C}$ in cumulates, and $800-908{ }^{\circ} \mathrm{C}$ in non-cumulate gabbros and are very similar to those of Ridolfi and Renzulli (2012) (Fig. 11). Temperatures were also calculated using the hornblende-plagioclase model of Holland and Blundy (1994). To increase the likelihood of
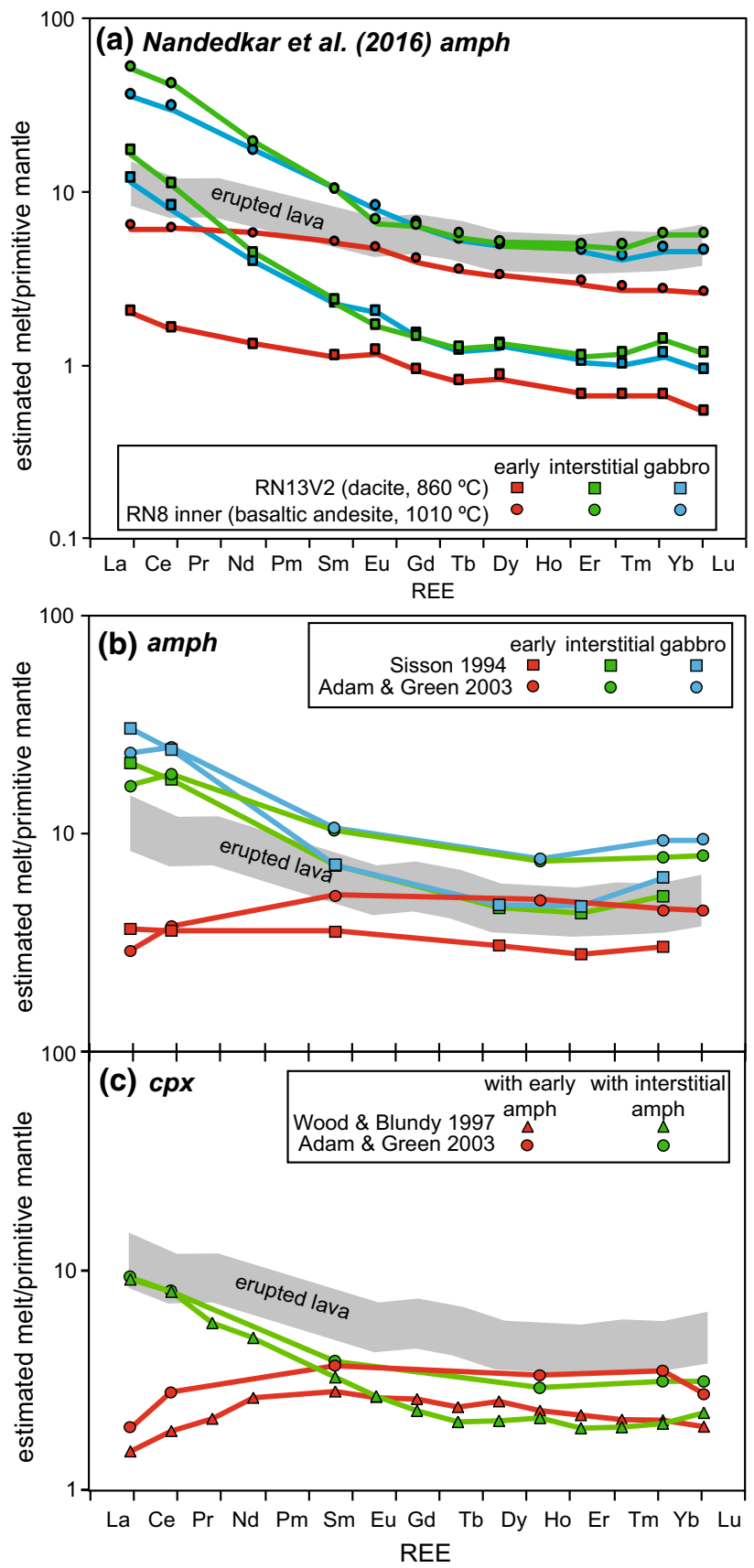

Fig. 12 Modelled melt compositions, normalised to primitive mantle (Palme and O'Neill 2003) in equilibrium with amphibole (a and b) and clinopyroxene (c) types using REE partition coefficients (Sisson 1994; Wood and Blundy 1997; Adam and Green 2003; Nandedkar et al. 2016). Grey shaded area is the range in whole-rock REE of erupted Martinique lavas

equilibrium between coexisting hornblende and plagioclase, only the compositions of crystal rims were used to calculate temperatures. The range in temperatures from each sample $\left(100-255^{\circ} \mathrm{C}\right)$ is larger than the range of those calculated from the Ridolfi and Renzulli (2012) and Putirka (2016) models (Online Resource 6; Fig. 11). Holland and 
Blundy (1994) model temperatures are also higher, with median values close to the hottest of Ridolfi and Renzulli (2012) (Fig. 11). The increased range of temperatures is likely a consequence of disequilibrium between plagioclase and amphibole, particularly in samples with interstitial (late-stage) amphibole (e.g. samples MQ11 and MQ14; Fig. 11). Magnetite and ilmenite are only present together within four of the plutonic xenoliths, and these are classed as non-cumulate gabbros. Where present, temperatures can be estimated using the Fe-Ti oxide model of Ghiorso and Evans (2008). Model temperatures are lower when compared with the other methods $\left(646-909{ }^{\circ} \mathrm{C}\right.$; Fig. 11). This may be a reflection of different storage conditions and the formation of non-cumulate gabbros from more evolved melts.

Amphibole compositions have been shown to have a strong pressure dependence (e.g. Niida and Green 1999; Mandler and Grove 2016). The relative pressure changes between xenolith types are explored using the pressure sensitive Al-Tschermack substitution, shown by $\mathrm{Al}^{\mathrm{IV}}$ versus $\mathrm{Al}^{\mathrm{VI}}$ (Fig. 10c). There is no trend in $\mathrm{Al}^{\mathrm{IV}}$ versus $\mathrm{Al}^{\mathrm{VI}}$ within each xenolith type, with the exception of non-cumulate gabbro, indicating limited pressure control. This is particularly evident in hornblende gabbronorites, where $\mathrm{Al}^{\mathrm{VI}}$ shows a large range with little/no corresponding change in $\mathrm{Al}^{\mathrm{IV}}$ and therefore are likely to be controlled by variations in melt chemistry. However, differences in $\mathrm{Al}^{\mathrm{IV}}$ and $\mathrm{Al}^{\mathrm{VI}}$ between xenolith types suggest a relative shift in crystallisation pressures between non-cumulate gabbro and hornblende gabbronorite at lower pressures, and hornblende gabbro, hornblende-olivine gabbro and plagioclase hornblendite at higher pressures (Fig. 10c). Pressure estimates using the amphibole only barometers of Putirka (2016), Ridolfi et al. (2010) and Ridolfi and Renzulli (2012) have been shown to have very large uncertainties (Erdmann et al. 2014; Putirka 2016) and were therefore not calculated for this study.

The comparison to experimental studies suggests that all Martinique assemblages can be produced under high water contents and pressures $\leq 0.4 \mathrm{GPa}$ corresponding to depths of $\leq 15 \mathrm{~km}$. Therefore, all plutonic xenoliths from Martinique are samples from mid-upper crustal storage regions and high water contents play an important role in the petrogenesis of magmas. The high anorthite content in plagioclase, high wollastonite content in clinopyroxene, and amphibole compositions indicate crystallisation from a hydrous magma (Gaetani et al. 1993; Sisson and Grove 1993a; Claeson and Meurer 2004). The presence of amphibole within Martinique plutonic xenoliths suggests that mid-upper crystal mushes can act as a sponge, storing and supplying the final erupted melts with water. Davidson and Wilson (2011) apply the geohygrometer of Pichavant and Macdonald (2007) to Martinique lavas, which gives water contents of 3.1-4.5 wt $\% \mathrm{H}_{2} \mathrm{O}$ (assuming a temperature of crystallisation of $1050{ }^{\circ} \mathrm{C}$ ). Such $\mathrm{H}_{2} \mathrm{O}$ contents are consistent with extensive amphibole crystallisation in deep crustal magma reservoirs (Davidson and Wilson 2011), such as the storage regions we directly analyse in this study.

No plagioclase-free assemblages were sampled from Martinique, and there is no evidence that any Martinique plutonic xenoliths have an origin in the lower crust. In hydrous conditions at greater pressures and depths, plagioclase is likely to be absent (Melekhova et al. 2015). Plagioclase-free assemblages have been sampled on Grenada (Stamper et al. 2014) and St. Vincent (Tollan et al. 2012) to the south of the Lesser Antilles arc and plagioclase appears later in the crystallisation sequence in plutonic xenoliths from Grenada. These distinctions may reflect a different crustal structure beneath the islands (Boynton et al. 1979), coupled with a contrasting polybaric petrogenesis.

\section{Amphibole and reactive melt flow}

In contrast to Grenada (Stamper et al. 2014), plutonic xenoliths from Martinique do not have a consistent crystallisation sequence. This is particularly evident in the early or late appearance of amphibole, which are both texturally and compositionally distinct. A variable crystallisation sequence may suggest that the plutonic xenoliths from Martinique are formed from more than one parental melt with distinct evolutionary history and $\mathrm{H}_{2} \mathrm{O}$ content, or they represent the same melt at a different stage of evolution. Amphibole trace element chemistry, together with textural evidence, provides evidence that multiple melts were involved in the petrogenesis of Martinique plutonic xenoliths. Early crystallising (equant) amphibole is more aluminium rich (both $\mathrm{Al}^{\mathrm{IV}}$ and $\mathrm{Al}^{\mathrm{VI}}$ ) and has lower concentrations of incompatible trace elements (Online Resource 2), LREE and $\mathrm{Ba}$ than late (interstitial and poikilitic) amphibole (Fig. 10). Melt $\mathrm{SiO}_{2}$ (wt\%) in equilibrium with early and interstitial amphibole was estimated using formulations from Putirka (2016). Early amphibole returned melts with 50.3-52.8 wt\% $\mathrm{SiO}_{2}$ compared with more evolved compositions of 58.8-64.6 wt\% $\mathrm{SiO}_{2}$ from interstitial amphibole (Online Resource 7). Predicted melt compositions of $\sim 70 \mathrm{wt} \% \mathrm{SiO}_{2}$, and the similarity of mineral chemistry from non-cumulate gabbros and lavas suggests that the non-cumulate gabbros are associated with the final erupted magmas.

The question then arises as to whether the late-stage amphibole crystallised in a closed system from the residual melt after crystallisation of the other phases (e.g. McBirney and Noyes 1979; Morse 1996), or in an open system involving the input of percolating reactive melts or liquids (Reiners 1998; Coogan et al. 2000, 2001; Meurer and Claeson 2002; Leuthold et al. 2014; Smith 2014; Bouilhol et al. 2015; Stuart et al. 2016). It has been shown 
that the products of reactive liquid flow will differ from one produced by simple crystallisation along a liquid line of descent (Reiners 1998) and the addition of low degree melts cause large variations in incompatible trace elements. In Martinique samples, there is an order of magnitude variation in incompatible elements ( $\mathrm{Hf}$ and $\mathrm{Zr}$ ) in amphibole and clinopyroxene (Online Resource 2) and a fivefold variation in $\mathrm{La}$ of amphibole is observed within one sample (Fig. 9). Trace element concentrations of interstitial amphibole do not follow the trend predicted if fractional crystallisation controlled the melt chemistry during amphibole crystallisation (Fig. 10d). This suggests that there has been some addition of melt into the system. This evidence is supported by the lack of a negative Eu anomaly in interstitial amphibole. If interstitial amphibole crystallised from a residual melt after significant plagioclase crystallisation, then the amphibole should have a negative Eu anomaly. This implies that the invading melt was yet to undergo plagioclase saturation, or that the melt was more water-rich and oxidising, leading to the suppression of the Eu anomaly in high An plagioclase (Philpotts 1970; Deering and Bachmann 2010).

Amphibole partition coefficients from calc-alkaline fractional crystallisation experiments of Nandedkar et al. (2016) were used to estimate melts in equilibrium with early, late and non-cumulate amphibole (Fig. 12a). Partition coefficients from a basaltic andesite (RN8 Inner), run at $1010{ }^{\circ} \mathrm{C}$ and a dacite (RN13V2) at $860{ }^{\circ} \mathrm{C}$ were chosen (Fig. 12a). Melt estimates using both experiments have the same REE profile shapes. However, higher melt REE concentrations are predicted using the partition coefficients from the basaltic andesite sample. Melts predicted using the late, interstitial amphibole has similar MREE-HREE pattern as the erupted lavas, but is significantly more enriched in LREE. In contrast, early crystallised amphibole returns melts with a flatter profile. The offset between REE concentrations predicted using the two experiments (RN8 Inner and RN13V2) highlights the extent to which amphibole partition coefficients vary with melt fractionation. Melts predicted using the partition coefficients from Sisson (1994) and Adam and Green (2003) have the same relative trends as those from Nandedkar et al. (2016) and suggest early amphibole grains crystallised from a primitive melt with a flat REE profile. The late, interstitial amphibole was crystallised from a melt enriched in LREE, similar to both the erupted lava whole-rock compositions and the melt in equilibrium with amphiboles in non-cumulate gabbros (Fig. 12b). This suggests that interstitial amphibole crystallised from evolved melts (58.8-64.6 wt\% $\mathrm{SiO}_{2}$ ) which either infiltrated into a pre-exiting cumulate pile (or mush), or the erupted melts were themselves generated in, and extracted from the crystal mush.
Clinopyroxene partition coefficients from Adam and Green (2003) and Wood and Blundy (1997) reveal the melts in equilibrium with clinopyroxene associated with both amphibole types have similarly contrasting REE compositions. The shape of the REE profile for melt in equilibrium with clinopyroxene associated with interstitial amphibole is very similar to the melt in equilibrium with interstitial amphibole. This suggests that a peritectic reaction occurred, in which clinopyroxene reacted with the infiltrating melt and was replaced by the interstitial amphibole. This geochemical evidence is in agreement with the textural observations (Fig. 3). However, the estimated REE concentrations are lower than both the erupted lavas and the melt in equilibrium with interstitial amphibole (Fig. 12). This observation implies that an addition of trace elements, in particular LREE into the system must have occurred after clinopyroxene crystallisation and before amphibole crystallisation. To assess the contribution of elements ( $\mathrm{Li}, \mathrm{Al}, \mathrm{Ti}, \mathrm{Ga}, \mathrm{Rb}, \mathrm{Sr}, \mathrm{Y}, \mathrm{Zr}, \mathrm{Hf}, \mathrm{Nb}, \mathrm{Ta}, \mathrm{Ba}, \mathrm{La}$, $\mathrm{Ce}, \mathrm{Sm}, \mathrm{Ho}, \mathrm{Yb}, \mathrm{Lu}, \mathrm{Th}, \mathrm{U}$ ) from clinopyroxene to produce reaction replacement amphiboles, the melt produced from the breakdown of clinopyroxene was modelled using partition coefficients (run at $1025^{\circ} \mathrm{C}, 0.5 \mathrm{GPa}$ ) from Adam and Green (2003) (Fig. 13). The chemistry of amphibole which then crystallised from the clinopyroxene melt was modelled using experimental amphibole partition coefficients (run at $1000{ }^{\circ} \mathrm{C}, 0.5 \mathrm{GPa}$ ) from Adam and Green (2003). If the modelled amphibole element concentrations were lower than natural interstitial amphibole, then an additional source of elements is needed (Fig. 13). The modal proportions of clinopyroxene and reaction replacement amphibole (e.g. MQ14; Fig. 2) suggest a significant proportion of clinopyroxene has been replaced by amphibole. Melting of up to $20 \%$ clinopyroxene can supply the system with the concentrations of $\mathrm{Al}, \mathrm{Ti}$ and the majority of trace elements needed to reproduce interstitial amphibole compositions. Apart from low degrees of meting ( $1 \% \mathrm{cpx}$ melting), a minimum additional source of $\mathrm{Sr}, \mathrm{Ba}, \mathrm{Y}$ and $\mathrm{Zr}$, as well as $\mathrm{H}_{2} \mathrm{O}$ and $\mathrm{Na}$ are needed in order to produce the interstitial amphibole (Fig. 13). Therefore, a water-rich plagioclase-undersaturated melt, carrying fluid mobile elements, reacted with the cumulate/mush pile to produce late-stage interstitial amphibole. The reaction of clinopyroxene with a melt, to form amphibole has been observed in cumulates (Best 1975; Debari et al. 1987; Coogan et al. 2001; Smith 2014; Bouilhol et al. 2015) and we believe this is a common process in Martinique plutonic xenoliths.

\section{Open system processes}

In addition to the percolating melts discussed above, plutonic xenoliths from Martinique display additional textural and chemical evidence of open system behaviour in the 
Li Al Ti Ga Rb Sr Y Zr Hf Nb Ta Ba La Ce Sm Ho Yb Lu Th U

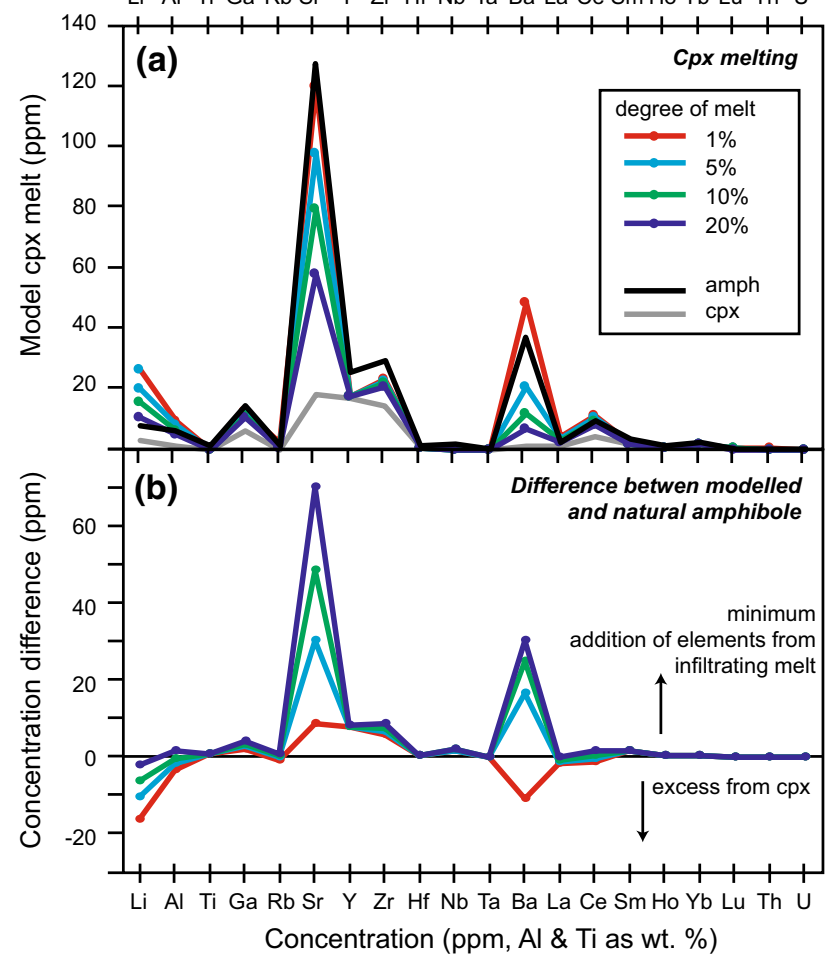

Fig. 13 a Modelled trace element concentrations of the liquid produced through varying degrees of clinopyroxene melting (coloured lines). The compositions of clinopyroxene (grey line) and associated interstitial amphibole (black line) are shown for comparison. b The difference in concentration between interstitial amphibole and the liquid produced from clinopyroxene melt. Strong positive values indicate those elements that were added through an additional source such as a percolating melt

form of crystal cargos. One olivine gabbro sample (MQ27) shows clear evidence for the assembly of crystal cargos. Clinopyroxene cores within this sample have a larger negative $\mathrm{Eu} / \mathrm{Eu}^{*}$ of $\sim 0.4$ and a lower $\mathrm{Mg} \#$ than the rims, which do not have a Eu anomaly and have a higher $\mathrm{Mg \#}$ (Fig. 8). This may suggest that the clinopyroxene grains began growing from a melt that had undergone significant plagioclase crystallisation, and then interacted with and continued to grow in a lesser-evolved, plagioclase-undersaturated melt. Alternatively, the rim-forming melt may be more water-rich and oxidising, leading to the suppression of the Eu anomaly in high An plagioclase (Philpotts 1970; Deering and Bachmann 2010). Oxygen fugacity estimates from sample MQ27 amphiboles are particularly oxidising (2.2-2.9 $\Delta$ NNO; Ridolfi and Renzulli 2012) and may therefore account for the absence of a negative Eu anomaly in clinopyroxene. This evidence suggests that the plutonic xenoliths from Martinique represent the assembly of grains during transport and emplacement, and are not formed through closed system crystallisation after emplacement of a magma body. The plagioclase-undersaturated melt is consistent with the estimated composition of the percolating reactive melt described above.

The xenoliths commonly contain vesiculated interstitial glass, and few samples have a locked crystal framework. This textural evidence suggests the plutonic xenoliths are capturing the disaggregation of a crystal mush (Passmore et al. 2012). This may represent interaction at the margins of magma reservoirs stored within a larger scale mush zone. In a number of samples, edges of crystals (plagioclase and olivine) in contact with the interstitial melt have a distinctive normally zoned reaction rim of more evolved compositions. This suggests that it was an evolved melt which infiltrated a cumulate pile or mush and 'postcumulus' growth of the crystals occurred prior to eruption. Within a number of samples, cross-veins of recrystallised material are present. In this case the infiltration of melt was confined to veins and did not disrupt the original crystal framework. The interstitial glass (Fig. 3a, f) contains skeletal plagioclase microlites, suggesting the host melt was rapidly quenched, and therefore the infiltration of the host melt must have occurred in a short timescale prior to eruption. Reacted rims on plagioclase are close to the compositions of plagioclase in non-cumulate gabbros (Fig. 8), and those from lavas (Pichavant et al. 2002). This provides evidence that the crystal mush interacted with the final erupted melts that are associated with non-cumulate gabbros.

Melt migration through crystal mushes is a common process within crustal storage regions (Leuthold et al. 2014; Solano et al. 2014). Exposed roots of volcanic arcs, such as the Kohistan palaeo-island arc, Pakistan (Bouilhol et al. 2015), Talkeetna, Alaska (Greene et al. 2006), Fjordland, New Zealand (Stuart et al. 2016) and exposed ultramafic complexes, Alaska (Murray 1972; Irvine 1974) allow for direct observations of the lower crust, and provide an analogue to Martinique plutonic xenoliths. In Kohistan, kilometre scale magmatic conduits are present in the lower crust, which melt rose through and reacted with the existing cumulate assemblages (Bouilhol et al. 2015). These conduits are similar to crustal feeder pipes observed in ultramafic complexes, Alaska (Murray 1972; Irvine 1974). Within these crustal sections there are outcrop scale variations in cumulate textures and crystallising phases, suggesting that it is possible to source variable plutonic xenoliths from relatively localised zones. The evidence of infiltrating melts and open system processes within Martinique cumulates suggest that they may be sourced from similar meltrich zones, which feed shallow storage regions within the Lesser Antilles crust.

\section{Amphibole sponge model}

Amphibole accumulation, represented by amphibole-bearing plutonic xenoliths, can be seen to have a control on the 
trace element signature of the lavas (Fig. 5). Amphibole preferentially incorporates MREE over HREE and therefore fractionation of amphibole with drive the melt to lower MREE/HREE (e.g. Dy/Yb) with an increasing concentration of an incompatible element (e.g. La). The fractionation of the final erupted amphibole-free lava assemblage does not have any leverage on the $\mathrm{Dy} / \mathrm{Yb}$ ratio, and therefore fractionation of the cumulate assemblage can explain the variation in $\mathrm{Dy} / \mathrm{Yb}$ displayed by the lavas (Fig. 6). The non-cumulate gabbro samples can be produced from the fractional crystallisation of the evolved melts generated after the initial 'cryptic' amphibole fractionation, and we therefore infer these samples to relate to crystallisation associated with the final erupted melt-dominant bodies stored in the shallow crust.

The data presented in this study suggest that a percolating melt through a crystal mush aided the breakdown of clinopyroxene and growth of amphibole (Best 1975; Debari et al. 1987; Smith 2014). The reactive transport of a melt through a clinopyroxene mush to crystallise amphibole will impart an amphibole fractionation signature irrespective of amphibole appearance or absence as a phenocryst phase (Smith 2014). Therefore, the presence of precursory clinopyroxene is a key requirement for the amphibole sponge in the mid-lower Lesser Antilles arc crust. The growth of interstitial amphibole as a replacement to clinopyroxene allows more interstitial liquid to be incorporated in the cumulates than would be possible in dryer basaltic systems with only amphibole-free assemblages (Meurer and Claeson 2002). Therefore, the mid-crustal storage regions provide a fertile source for melts and fluids to fuel eruptions and potentially increase the explosivity of the magmas that reach the surface.

\section{Plumbing system beneath Martinique}

The plutonic xenoliths from Martinique used in this study provide direct evidence of open system processes, and the majority were sourced from the mid-crust and represent regions of crystal mush, within which melts are both stored and generated. Melt segregation in hot zones (Sawyer 1994; Solano et al. 2012, 2014) provides mechanisms by which a largely crystal-free melt is separated from the early formed clinopyroxene and reaction replacement amphibole-rich mushes. We can infer that the lower crust was likely a deep crustal hot zone (Annen et al. 2006). Melts were generated and stored within this region and underwent early differentiation of olivine (plus other phases) from mantle-derived primitive melts. The relatively low Fo and $\mathrm{Ni}$ contents of olivine provide evidence of crystallisation from a melt that has undergone prior olivine fractionation. Melts that segregate from the deep crustal hot zone ascend and stall in the mid-crust, within the plagioclase stability field. The vast majority of cumulate xenoliths from Martinique represent storage within this mid-crustal mush zone. Variations in phase assemblages may relate to localised variations in water content and temperatures within the crystal mush. Hydrous reactive melts percolate through the cumulate pile, crystallising interstitial amphibole. A large proportion of the plutonic xenoliths contain evidence for percolative melt flow and therefore likely originated in melt-rich channels within a crystal mush (Bouilhol et al. 2015). For this reason, the erupted plutonic record may be biased to sampling melt-rich zones which can eventually transport parts of the cumulate pile into the host magmas in shallow reservoirs. Crystal poor, evolved melts generated within the mid-crustal mush zone segregate and ascend to their pre-eruptive storage in shallow magma reservoirs for some time prior to eruption. The non-cumulate gabbros generally have zoned crystal phases with more evolved compositions, some amphibole-free assemblages and whole-rock chemistries which resemble erupted lavas, and therefore appear to represent the plutonic equivalents of the final erupted melts, or frozen portions of magma chambers. The ability of amphibole-rich cumulates in the mid-crust to act as a sponge provides a source for water-rich magmas, which may eventually fuel the explosive eruptions characteristic of the Lesser Antilles volcanic arc.

\section{Conclusions}

Plutonic xenoliths from Martinique provide direct evidence for the amphibole sponge model in arc crust and the nature of the sub-volcanic plumbing system. The key findings from Martinique plutonic xenoliths are the following:

1. Crystallisation sequences of the plutonic xenoliths are variable, which could be accounted for by multiple sources of melt that differentiated at multiple depths. This observation is in contrast to plutonic xenoliths from other islands of the Lesser Antilles which have consistent crystallisation sequences.

2. All samples are inferred to be sourced from the midupper crust $\leq 15 \mathrm{~km}$, at pressures of $\leq 4 \mathrm{GPa}$ and crystallised under high water contents. Plutonic xenoliths of cumulate origin represent a mid-crustal storage region, whereas non-cumulate gabbros and gabbronorites are associated with melt-dominant bodies stored in the upper crust.

3. There is clear textural and geochemical evidence for open system processes including crystal cargos and percolating reactive melts. Therefore, plutonic xenoliths from Martinique represent mid-crustal crystal mushes in which melts can be both stored and generated. 
4. Precursory clinopyroxene is a key requirement of amphibole sponge in the Lesser Antilles arc crust. Percolating melts, react with clinopyroxene to form interstitial amphibole. This is seen both texturally and in trace element concentrations of associated clinopyroxene and amphibole, where the chemistries of precursory clinopyroxene, together with an evolved percolating melt, control the composition of the later crystallised amphibole.

Acknowledgments Work by GFC was funded by a NERC standard grant (NE/K004328/1). We thank Stuart Kearns for assistance and advice with the Electron Microprobe in Bristol and Chris Ottley and Geoff Nowel for continued help and support in the Durham Geochemistry labs. Richard Arculus, Luca Ziberna, Lena Melekhova, Richard Brooker and Madeleine Humphreys are thanked for many insightful cumulate discussions. Reviews by Etienne Medard, Daniel Smith and editorial handling by Othmar Müntener are greatly appreciated.

Open Access This article is distributed under the terms of the Creative Commons Attribution 4.0 International License (http://creativecommons.org/licenses/by/4.0/), which permits unrestricted use, distribution, and reproduction in any medium, provided you give appropriate credit to the original author(s) and the source, provide a link to the Creative Commons license, and indicate if changes were made.

\section{References}

Adam J, Green TH (2003) The influence of pressure, mineral composition and water on trace element partitioning between clinopyroxene, amphibole and basanitic melts. Eur J Miner 15:831-841

Annen C, Blundy JD, Sparks RSJ (2006) The genesis of intermediate and silicic magmas in deep crustal hot zones. J Petrol 47(3):505-539

Arculus R (1976) Geology and geochemistry of the alkali basaltandesite association of Grenada, Lesser Antilles island arc. Geol Soc Am Bull 87(4):612-624

Arculus RJ, Wills KJA (1980) The petrology of plutonic blocks and inclusions from the Lesser Antilles Island Arc. J Petrol 21(4):743-799

Bédard JH, Sparks RSJ, Renner R, Cheadle MJ, Hallworth MA (1988) Peridotite sills and metasomatic gabbros in the eastern layered series of the Rum complex. J Geol Soc 145:207-224. doi:10.1144/gsjgs.145.2.0207

Best MG (1975) Amphibole-bearing cumulate inclusions, Grand Canyon, Arizona and their bearing on silica-undersaturated hydrous magmas in the upper mantle. J Petrol 16(1):212-236

Bezard R, Turner S, Davidson JP, Macpherson CG, Lindsay JM (2015) Seeing through the effects of crustal assimilation to access the source composition beneath the southern Lesser Antilles Arc. J Petrol 56(4):815-844

Bouilhol P, Schmidt MW, Burg JP (2015) Magma transfer and evolution in channels within the arc crust: the pyroxenitic feeder pipes of Sapat (Kohistan, Pakistan). J Petrol 56(7):1309-1342

Bouysse P, Westercamp D (1990) Subduction of Atlantic aseismic ridges and Late Cenozoic evolution of the Lesser Antilles Island-Arc. Tectonophysics 175(4):349-380. doi:10.1016/0040-1951(90)90180-g

Boynton CH, Westbrook GK, Bott MHP, Long RE (1979) Seismic refraction investigation of crustal structure beneath the Lesser-Antilles Island Arc. Geophys J Roy Astron Soc 58(2):371-393. doi:10.1111/j.1365-246X.1979.tb01031.x

Brown G, Holland J, Sigurdsson H, Tomblin J, Arculus R (1977) Geochemistry of the Lesser Antilles volcanic island arc. Geochim Cosmochim Acta 41(6):785-801

Claeson D, Meurer W (2004) Fractional crystallization of hydrous basaltic "arc-type" magmas and the formation of amphibolebearing gabbroic cumulates. Contrib Miner Petrol 147(3):288304. doi:10.1007/s00410-003-0536-0

Coogan LA, Saunders AD, Kempton PD, Norry MJ (2000) Evidence from oceanic gabbros for porous melt migration within a crystal mush beneath the Mid-Atlantic Ridge. Geochem Geophys Geosyst 1:2000GC000072

Coogan LA, Wilson RN, Gillis KM, MacLeod CJ (2001) Near-solidus evolution of oceanic gabbros: insights from amphibole geochemistry. Geochim Cosmochim Acta 65(23):4339-4357

Davidson JP (1983) Lesser Antilles isotopic evidence of the role of subducted sediment in island-arc magma genesis. Nature 306(5940):253-256. doi:10.1038/306253a0

Davidson JP (1986) Isotopic and trace-element constraints on the petrogenesis of subduction-related lavas from Martinique, Lesser Antilles. J Geophys Res-Solid Earth Planets 91(B6):5943-5962. doi:10.1029/JB091iB06p05943

Davidson J, Wilson M (2011) Differentiation and source processes at Mt Pelee and the Quill; active volcanoes in the lesser antilles arc. J Petrol 52(7-8):1493-1531. doi:10.1093/petrology/egq095

Davidson J, Turner S, Handley H, Macpherson C, Dosseto A (2007) Amphibole 'sponge' in arc crust? Geology 35(9):787-790. doi:10.1130/g23637a.1

Debari S, Kay SM, Kay RW (1987) Ultramafic xenoliths from Adagdak Volcano, Adak, Aleutian-Islands, Alaska: deformed igneous cumulates from the Moho of the island-arc. J Geol 95(3):329-341

Deering CD, Bachmann O (2010) Trace element indicators of crystal accumulation in silicic igneous rocks. Earth Planet Sci Lett 297(1-2):324-331

Erdmann S, Martel C, Pichavant M, Kushnir A (2014) Amphibole as an archivist of magmatic crystallization conditions: problems, potential, and implications for inferring magma storage prior to the paroxysmal 2010 eruption of Mount Merapi, Indonesia. Contrib Miner Petrol 167(6):23. doi:10.1007/s00410-014-1016-4

Gaetani GA, Grove TL, Bryan WB (1993) The influence of water on the petrogenesis of subduction-related igneous rocks. Nature 365(6444):332-334. doi:10.1038/365332a0

Germa A, Quidelleur X, Labanieh S, Chauvel C, Lahitte P (2011) The volcanic evolution of Martinique Island: insights from K-Ar dating into the Lesser Antilles arc migration since the Oligocene. J Volcanol Geoth Res 208(3-4):122-135. doi:10.1016/j. jvolgeores.2011.09.007

Ghiorso MS, Evans BW (2008) Thermodynamics of rhombohedral oxide solid solutions and a revision of the Fe-Ti two-oxide geothermometer and oxygen-barometer. Am J Sci 308(9):957-1039. doi: $10.2475 / 09.2008 .01$

Greene AR, Debari SM, Kelemen PB, Blusztajn J, Clift PD (2006) A detailed geochemical study of island arc crust: the Talkeetna Arc section, south-central Alaska. J Petrol 47(6):1051-1093

Heath E, Macdonald R, Belkin H, Hawkesworth C, Sigurdsson H (1998) Magmagenesis at Soufriere Volcano, St Vincent, Lesser Antilles Arc. J Petrol 39(10):1721-1764

Holland T, Blundy J (1994) Non-ideal interactions in calcic amphiboles and their bearing on amphibole-plagioclase thermometry. Contrib Miner Petrol 116(4):433-447. doi:10.1007/bf00310910

Holness MB (2005) Spatial constraints on magma chamber replenishment events from textural observations of cumulates: the Rum layered intrusion, Scotland. J Petrol 46(8):1585-1601. doi:10.1093/petrology/egi027 
Holness MB, Hallworth MA, Woods A, Sides RE (2007) Infiltration metasomatism of cumulates by intrusive magma replenishment: the Wavy Horizon, Isle of Rum, Scotland. J Petrol 48(3):563587. doi:10.1093/petrology/eg1072

Irvine TN (1974) Petrology of the Duke Island ultramafic complex southeastern Alaska. Geol Soc Am Mem 138:1-244

Kiddle EJ, Edwards BR, Loughlin SC, Petterson M, Sparks RSJ (2010) Crustal structure beneath Montserrat, Lesser Antilles, constrained by xenoliths, seismic velocity structure and petrology. Geopysical Research Letters 31:L00E11

Kodaira S, Sato T, Takahashi N, Miura S, Tamura Y, Tatsumi Y, Kaneda Y (2007) New seismological constraints on growth of continental crust in the Izu-Bonin intra-oceanic arc. Geology 35(11):1031-1034. doi:10.1130/g23901a.1

Labanieh S, Chauvel C, Germa A, Quidelleur X (2012) Martinique: a clear case for sediment melting and slab dehydration as a function of distance to the trench. J Petrol 53(12):2441-2464. doi:10.1093/petrology/egs055

Leake BE, Woolley AR, Birch WD, Burke EAJ, Ferraris G, Grice JD, Hawthorne FC, Kisch HJ, Krivovichev VG, Schumacher JC, Stephenson NCN, Whittaker EJW (2003) Nomenclature of amphiboles: additions and revisions to the International Mineralogical Association's 1997 recommendations. Can Miner 41:1355-1362. doi:10.2113/gscanmin.41.6.1355

Leuthold J, Blundy JD, Holness MB, Sides R (2014) Successive episodes of reactive liquid flow through a layered intrusion (Unit 9, Rum Eastern Layered Intrusion, Scotland). Contrib Miner Petrol 168:1021

Lewis JF (1973) Mineralogy of the ejected plutonic blocks of the Soufriere Volcano St. Vincent: olivine, pyroxene, amphibole and magnetite paragenesis. Contrib Miner Petrol 38:197-220

Macdonald R, Hawkesworth CJ, Heath E (2000) The Lesser Antilles volcanic chain: a study in are magmatism. Earth Sci Rev 49(14):1-76. doi:10.1016/s0012-8252(99)00069-0

Mandler BE, Grove TL (2016) Controls on the stability and composition of amphibole in the Earth's mantle. Contrib Miner Petrol 171(8-9):68

Martel C, Pichavant M, Holtz F, Scaillet B, Bourdier JL, Traineau $\mathrm{H}$ (1999) Effects of $\mathrm{f}(\mathrm{O} 2)$ and $\mathrm{H} 2 \mathrm{O}$ on andesite phase relations between 2 and 4 kbar. J Geophys Res-Solid Earth 104(B12):29453-29470. doi:10.1029/1999jb900191

McBirney AR, Noyes RM (1979) Crystallization and layering of the Skaergaard Intrusion. J Petrol 20(3):487-554

McKenzie D (2011) Compaction and crystallization in magma chambers: towards a model of the Skaergaard Intrusion. J Petrol 52(5):905-930

Médard E, Schmidt MW, Schiano P (2004) Liquidus surfaces of ultracalcic primitive melts: formation conditions and sources. Contrib Miner Petrol 148(2):201-215

Melekhova E, Blundy J, Robertson R, Humphreys MCS (2015) Experimental Evidence for Polybaric Differentiation of Primitive Arc Basalt beneath St. Vincent, Lesser Antilles. J Petrol 56(1):161-192. doi:10.1093/petrology/egu074

Meurer WP, Claeson DT (2002) Evolution of crystallizing interstitial liquid in an arc-related cumulate determined by LA ICP-MS mapping of a large amphibole oikocryst. J Petrol 43(4):607-629

Morse SA (1996) Kiglapait mineralogy III: olivine compositions and Rayleigh fractionation models. J Petrol 37(5):1037-1061

Murray CG (1972) Zoned ultramafic complexes of the Alaskan type: feeder pipes of andesitic volcanoes. GSA Memoirs 132:313-336

Nandedkar RH, Hürlimann N, Ulmer P, Müntener O (2016) Amphibole-melt trace element partitioning of fractionating calc-alkaline magmas in the lower crust: an experimental study. Contrib Miner Petrol 171:71

Niida K, Green DH (1999) Stability and chemical composition of pargasitic amphibole in MORB pyrolite under upper mantle conditions. Contrib Miner Petrol 135(1):18-40
Palme H, O'Neill HSC (2003) Cosmochemical estimates of mantle composition. Treatise Geochem 2:1-38

Passmore E, Maclennan J, Fitton G, Thordarson T (2012) Mush disaggregation in basaltic magma chambers: evidence from the $\mathrm{AD}$ 1783 Laki Eruption. J Petrol 53(12):2593-2623

Philpotts JA (1970) Redox estimation from a calculation of $\mathrm{Eu}^{2+}$ and $\mathrm{Eu}^{3+}$ concentrations in natural phases. Earth Planet Sci Lett 9(3):257-268

Pichavant M, Macdonald R (2007) Crystallization of primitive basaltic magmas at crustal pressures and genesis of the calc-alkaline igneous suite: experimental evidence from St Vincent, Lesser Antilles arc. Contrib Miner Petrol 154(5):535-558. doi:10.1007/ s00410-007-0208-6

Pichavant M, Mysen BO, Macdonald R (2002) Source and H2O content of high-MgO magmas in island arc settings: an experimental study of a primitive calc-alkaline basalt from St. Vincent, Lesser Antilles arc. Geochim Cosmochim Acta 66(12):2193-2209. doi:10.1016/s0016-7037(01)00891-2

Putirka K (2016) Amphibole thermometers and barometers for igneous systems and some implications for eruption mechanisms of felsic magmas at arc volcanoes. Am Mineral 101:841-858

Reiners PW (1998) Reactive melt transport in the mantle and geochemical signatures of mantle-derived magmas. J Petrol 39(5):1039-1061. doi:10.1093/petrology/39.5.1039

Ridolfi F, Renzulli A (2012) Calcic amphiboles in calc-alkaline and alkaline magmas: thermobarometric and chemometric empirical equations valid up to $1,130 \mathrm{~A}$ degrees $\mathrm{C}$ and $2.2 \mathrm{GPa}$. Contrib Miner Petrol 163(5):877-895. doi:10.1007/s00410-011-0704-6

Ridolfi F, Renzulli A, Puerini M (2010) Stability and chemical equilibrium of amphibole in calc-alkaline magmas: an overview, new thermobarometric formulations and application to subduction-related volcanoes. Contrib Miner Petrol 160(1):45-66. doi:10.1007/s00410-009-0465-7

Sawyer EW (1994) Melt segregation in the continental crust. Geology 22(11):1019-1022

Schiano P, Eiler JM, Hutcheon ID, Stolper EM (2000) Primitive CaOrich, silica-undersaturated melts in island arcs: Evidence for the involvement of clinopyroxene-rich lithologies in the petrogenesis of arc magmas. Geochem Geophys Geosyst 1(5):1018

Schlaphorst D, Kendall JM, Blundy JD, Melekhova E, Baptie B, Latchman JL, Bouin MP, Tait S (2014) Observations and modeling of the crustal structure and Moho strength variation along the Lesser Antilles Arc. American Geophysical Union, Fall Meeting 2014, abstract 2014AGUFM.T53E..07S

Sisson TW (1994) Hornblende-melt trace-element partitioning measured by Ion Microprobe. Chem Geol 117(1-4):331-344. doi:10.1016/0009-2541(94)90135-x

Sisson TW, Grove TL (1993a) Experimental investigations of the role of $\mathrm{H}_{2} \mathrm{O}$ in calc-alkaline differentiation and subduction zone magmatism. Contrib Miner Petrol 113(2):143-166. doi:10.1007/ bf00283225

Sisson TW, Grove TL (1993b) Temperatures and $\mathrm{H}_{2} \mathrm{O}$ contents of low- $\mathrm{MgO}$ high-alumina basalts. Contrib Miner Petrol 113(2):167-184. doi:10.1007/bf00283226

Smith DJ (2014) Clinopyroxene precursors to amphibole sponge in arc crust. Nat Commun 5:6. doi:10.1038/ncomms5329

Smith AL, Roobol MJ, Gunn BM (1980) The Lesser Antilles-A discussion of the Island arc magmatism. Bulletin Volcanologique 43(2):287-302

Solano JMS, Jackson MD, Sparks RSJ, Blundy JD, Annen C (2012) Melt segregation in deep crustal hot zones: a Mechanism for chemical differentiation, crustal assimilation and the formation of Evolved magmas. J Petrol 53(10):1999-2026. doi:10.1093/ petrology/egs041

Solano JMS, Jackson MD, Sparks RSJ, Blundy J (2014) Evolution of major and trace element composition during melt 
migration through crystalline mush: implications for chemical differentiation in the crust. Am J Sci 314(5):895-939. doi: $10.2475 / 05.2014 .01$

Stamper CC, Blundy JD, Arculus RJ, Melekhova E (2014) Petrology of Plutonic Xenoliths and Volcanic Rocks from Grenada, Lesser Antilles. J Petrol 55(7):1353-1387. doi:10.1093/petrology/ egu027

Streckeisen A (1976) To each plutonic rock its proper name. Earth Sci Rev 12(1):1-33. doi:10.1016/0012-8252(76)90052-0

Stuart CA, Piazolo S, Daczko NR (2016) Mass transfer in the lower crust: Evidence for incipient melt assisted flow along grain boundaries in the deep arc granulites of Fiordland, New Zealand. Geochemistry, Geophysics, Geosystems. Accepted Author Manuscript. doi:10.1002/2015GC006236

Tamura Y, Gill JB, Tollstrup D, Kawabata H, Shukuno H, Chang Q, Miyazaki T, Takahashi T, Hirahara Y, Kodaira S, Ishizuka O, Suzuki T, Kido Y, Fiske RS, Tatsumi Y (2009) Silicic Magmas in the Izu-Bonin Oceanic Arc and Implications for Crustal Evolution. J Petrol 50(4):685-723. doi:10.1093/petrology/egp017
Tollan PME, Bindeman I, Blundy JD (2012) Cumulate xenoliths from St. Vincent, Lesser Antilles Island Arc: a window into upper crustal differentiation of mantle-derived basalts. Contrib Miner Petrol 163(2):189-208. doi:10.1007/s00410-011-0665-9

Turner S, Hawkesworth C, van Calsteren P, Heath E, MacDonald R, Black S (1996) U-series isotopes and destructive plate margin magma genesis in the Lesser Antilles. Earth and Planetary Science Letters 142(1):191-207

Wadge G, Shepherd J (1984) Segmentation of the Lesser Antilles subduction zone. Earth and Planetary Science Letters 71(2):297-304

Wager LR, Brown GM, Wadsworth WJ (1960) Types of igneous cumulates. J Petrol 1:73-85

Westercamp D, Andreieff P, Bouysse P, Cottez S, Battistini R (1989). Martinique. Carte geologique a' 1/50 000. Orleans: BRGM

Wood BJ, Blundy JD (1997) A predictive model for rare earth element partitioning between clinopyroxene and anhydrous silicate melt. Contrib Miner Petrol 129(2-3):166-181. doi:10.1007/ s004100050330 